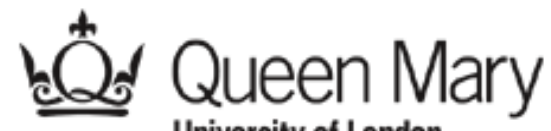 \\ University of London
}

Centre for Globalization Research

School of Business and Management

\section{No Extension without Representation? Evidence from a Natural Experiment in Collective Bargaining}

CGR Working Paper 68

\section{Alexander Hijzen and Pedro S. Martins}

\begin{abstract}
In many countries, notably across Europe, collective bargaining coverage is enhanced by government-issued extensions that widen the reach of collective agreements beyond their signatory parties to all firms and workers in the same sector. This paper analyses the causal impact of such extensions on employment using a natural experiment in Portugal: the immediate suspension by the government that took office in 21 June 2011 of the (until then) nearly automatic extensions. The combination of this suspension and the time needed for processing the extension applications resulted in a sharp and unanticipated decline in the extension probability of agreements signed several months earlier, around 1 March 2011. Our results, based on a regression discontinuity design and matched employer-employeeagreement panel data, suggest that extensions had a negative impact on employment growth. Moreover, the effects tend to be concentrated amongst non-affiliated firms. The lack of representativeness of employer associations is a potentially important factor behind the adverse effect of extensions. Another is the role of retro-activity in combination with the administrative delay in processing extensions. This is particularly relevant in the context of a recession.
\end{abstract}

Keywords: collective bargaining, industrial relations, employer associations, wage setting, employment

JEL codes: J52, J58, J21

http://www.busman.qmul.ac.uk/cgr 


\title{
No Extension without Representation? Evidence from a Natural Experiment in Collective Bargaining ${ }^{1}$
}

\author{
Alexander Hijzen and Pedro S. Martins
}

\begin{abstract}
In many countries, notably across Europe, collective bargaining coverage is enhanced by governmentissued extensions that widen the reach of collective agreements beyond their signatory parties to all firms and workers in the same sector. This paper analyses the causal impact of such extensions on employment using a natural experiment in Portugal: the immediate suspension by the government that took office in 21 June 2011 of the (until then) nearly automatic extensions. The combination of this suspension and the time needed for processing the extension applications resulted in a sharp and unanticipated decline in the extension probability of agreements signed several months earlier, around 1 March 2011. Our results, based on a regression discontinuity design and matched employer-employee-agreement panel data, suggest that extensions had a negative impact on employment growth. Moreover, the effects tend to be concentrated amongst non-affiliated firms. The lack of representativeness of employer associations is a potentially important factor behind the adverse effect of extensions. Another is the role of retro-activity in combination with the administrative delay in processing extensions. This is particularly relevant in the context of a recession.
\end{abstract}

JEL Classification Numbers: J52, J58, J21

Keywords: collective bargaining, industrial relations, employer associations, wage setting, employment

\footnotetext{
${ }^{1}$ Much of the work for this paper was conducted when the authors were visiting the International Monetary Fund. The authors are grateful to the International Monetary Fund for its hospitality and would like to thank Stijn Broecke, Romain Duval, Andrea Garnero, Eric Gould, Joana Silva and participants at seminars/workshops at CEPREMAP (Paris), Tinbergen Institute (Amsterdam), the IMF (Washington DC), Queen Mary University of London and Nova School of Business and Economics (Lisbon) for useful discussions, comments and suggestions. The views expressed in this paper are those of the authors and cannot be attributed to the IMF, the OECD or their member countries. Also the authors are responsible for any remaining errors. Martins was Secretary of State of Employment in the Government of Portugal in 2011-2013 and was co-responsible for designing and implementing the policy evaluated in this paper.
} 


\section{INTRODUCTION}

Since the global financial crisis, there has been a renewed interest in the role of collective bargaining for economic performance. Well-functioning collective bargaining systems can promote high and stable employment by increasing the responsiveness of working conditions to economic shocks. Such systems either allow aligning negotiated wages with macro-economic conditions through effective coordination or with firm-level conditions through decentralization (Blanchard et al., 2013; Dustmann et al, 2014). One may also argue that by supporting wages, collective bargaining has the potential of promoting consumption and hence aggregate demand, which may be of particular relevance where there is economic slack, inflation is low and space for macroeconomic policy stimulus is limited. However, if not functioning optimally, collective bargaining systems also run the risk of reducing the responsiveness of working conditionssuch as wages and working hours - to aggregate shocks. As a result, collective bargaining may increase the social costs of economic downturns by slowing labor market adjustment and increasing the reliance on labor shedding.

In many countries, particularly in Europe, collective bargaining coverage is determined to an important extent by extensions issued by governments. These administrative extensions widen the reach of collective agreements beyond their signatory parties - typically firms affiliated with subscribing employer associations and workers affiliated with subscribing unions - to all firms and workers in the same sector. Such extensions have allowed collective bargaining coverage to remain particularly high in several countries, even when union density - the share of workers affiliated to a union—has declined

A first quantitative indication of the role of extensions for collective bargaining coverage can be obtained by comparing trade union density with collective bargaining coverage (Figure 1). In countries where the difference between union density and bargaining coverage is large, such as France, extensions tend to be important. ${ }^{2}$ Moreover, their economic significance has tended

\footnotetext{
${ }^{2}$ However, (administrative) extensions are not the only factor behind the difference. In many countries, agreements apply ergo omnes to all workers in a firm that co-signs a collective agreement irrespective of their union membership status. This extends the coverage of the agreement within the firm. However, this is not the case in Portugal. In the absence of extensions, agreements only apply to unionized workers in affiliated firms (“double affiliation principle”).
} 
to increase over time as trade union density has declined while coverage has remained largely stable.

Figure 1. Collective bargaining coverage and trade union density

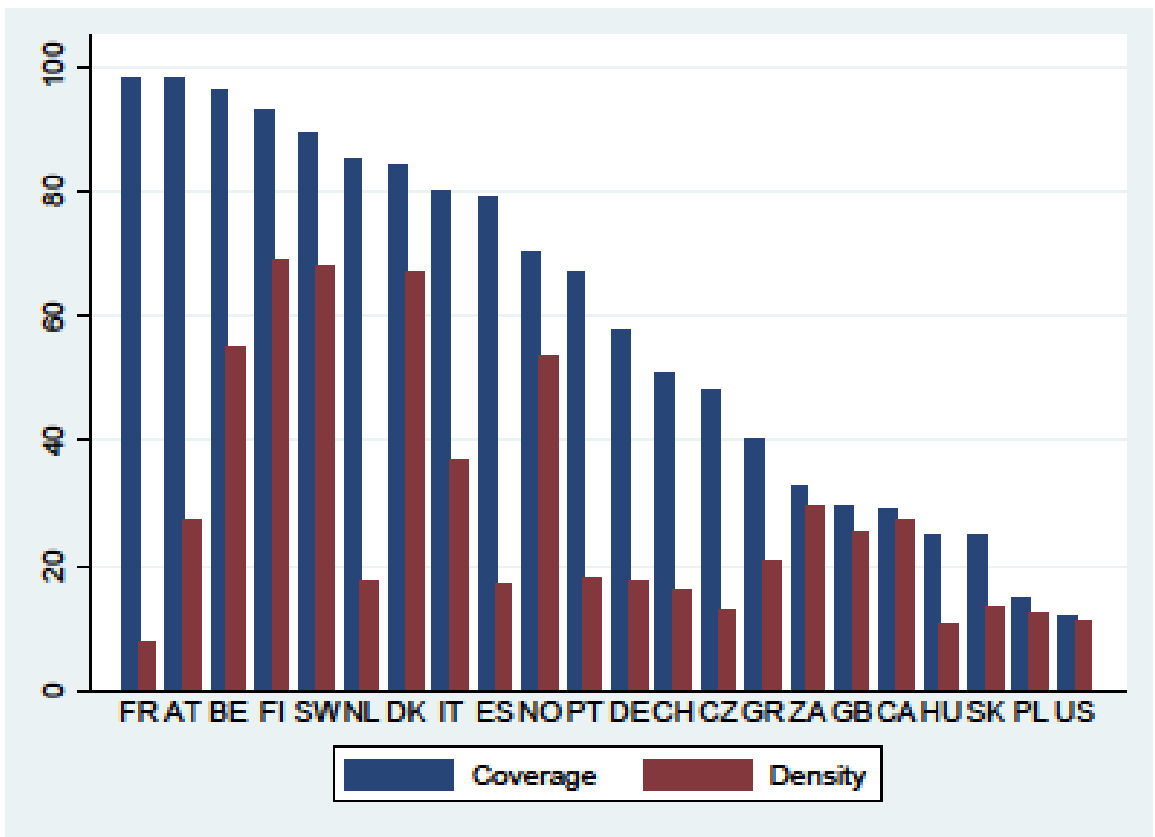

Source: ILO (2013)

Early theoretical work has highlighted potential concerns about the role of extensions for employment, particularly when the social partners are unrepresentative of the sector as a whole. Moll (1996) presents a model of administrative extensions with heterogeneous firms in which only some fraction of the largest and most productive firms is engaged in collective bargaining. He shows that these firms benefit from extensions because it reduces competition from less productive firms and allows paying lower wages. By contrast, non-unionized low productivity firms need to pay higher wages, reducing the scope for low-wage competition. In the same spirit, Haucaup et al. (2001) show that employer associations can use extensions as an anticompetitive device by raising the labor cost of their non-organized rivals.

A number of recent papers have analyzed the role of administrative extensions empirically. Murtin et al. (2014) show, using country-level panel data, that excess coverage -the difference between bargaining coverage and union density - is not systematically correlated with (higher) unemployment. However, they also present evidence that suggests that the effects are more 
adverse in countries where the tax wedge - the difference between labor costs and take-home pay for employees - is higher. Magruder (2012) finds, in the case of South Africa, that extensions in industries within specific districts reduce employment by around 10\% compared with that in the same industry in uncovered neighbouring districts. Martins (2014) analyses the effects of extensions in Portugal during the period 2008-2011. Drawing on the scattered timing of extensions, he finds that extensions tend to decrease sectoral employment by $2 \%$ over the four months following an extension, particularly among smaller firms. ${ }^{3}$ By contrast, Hartog et al. (2001) do not find much of a role for extensions in the Netherlands. ${ }^{4}$ Importantly, none of these previous papers has directly examined the role of representativeness by taking account of the membership of firms to employer associations. Yet, it could well be that more representative employer associations negotiate more representative agreements that suit the majority of firms in their sector, thereby yielding less adverse employment effects (if any) compared with less representative employer associations.

This paper seeks to contribute to the literature on collective bargaining by providing new insights on the causal impact of extensions. More specifically, this paper analyses the impact of administrative extensions of collective agreements on employment growth in affiliated versus non-affiliated firms. Importantly, this sheds light on the extent to which concerns about representativeness are warranted in practice. The analysis is based on a natural experiment in Portugal that resulted from the immediate suspension of extensions by the new government that took office in June 2011. We employ a regression discontinuity design (RDD) that exploits the standard administrative delay between the time an agreement is concluded until the time it is extended in combination with the suspension of extensions in June 2011. Importantly, this resulted in a sharp and unanticipated decline in the probability that an extension was issued several months prior to the change in government and the change in policy regarding extensions.

Our main result is that extensions had a negative effect on employment growth during the period 2010-2011, amounting to 5 percentage points or more depending on the specification. These

\footnotetext{
${ }^{3}$ See also Diez-Catalan \& Villanueva (2015), who explore the contrast in collective bargaining in Spain before and after the emergence of the 2008 financial crisis.

${ }^{4}$ De Ridder and Euwals (2016) provide suggestive evidence that extensions increase wages, but do not consider the role of extensions for employment.
} 
large effects are likely to reflect to an important extent the specific context of recession during which the natural experiment took place. Moreover, the negative impact of extensions tends to be concentrated among non-affiliated firms. This suggests that the lack of representativeness of employer associations is a potentially important factor behind the adverse effect of extensions. The adverse effects of extensions are also larger the longer the administrative delay in processing extensions. The latter reflects the role of retro-activity, which refers to the requirement in place until the 2012 labor reform for non-affiliated firms to pay wage arrears over the period from the entry-into-force of the original collective agreement to the time when the extension is issued. Finally, there is some evidence that suggests that the adverse effect of extensions on employment growth comes about through their impact on wages in the bottom part of the distribution. This hints at a potential trade-off between the wage and employment effects of extensions.

The remainder of this paper is structured as follows. Section 2 provides the economic and institutional context around the time of the natural experiment. Section 3 describes the natural experiment, explains how this is exploited using a regression discontinuity design and discusses the validity of this approach in the present context. Section 4 discusses our matched employeremployee dataset merged with information on collective agreements and extensions (including their timings). Section 5 presents the evidence on the impact of administrative extensions across the board as well as separately for affiliated and non-affiliated firms. It also analyses how the impact of extensions depends on the degree of representativeness of employer associations and the role of retro-activity in combination with the administrative delay in processing extensions. Section 6 presents some additional results in relation to wage inequality. Section 7 concludes.

\section{ECONOMIC AND INSTITUTIONAL CONTEXT}

During the 2000s, Portugal experienced low growth, declining international competitiveness and deepening macroeconomic imbalances (Blanchard, 2007). As a result, Portugal had to face up to the global financial crisis starting from a fragile situation. The global financial crisis then prompted large increases in public deficits and loss of market access amid a sudden stop in capital flows, leading to a request for financial assistance in April 2011 directed towards the European Union, the European Central Bank and the International Monetary Fund. Financial support was made available, conditionally on a number of structural reforms and adjustment 
measures. Given the potential importance of real wage adjustment to minimize employment losses, structural reforms also included measures on collective bargaining.

Until mid-2011, collective bargaining in Portugal - as in many other European countries - took place almost exclusively at the sectoral level, being driven by negotiations between employer associations and trade unions. Firm-level bargaining was essentially limited to state-owned and former state-owned companies and a small number of other very large firms or holdings. Moreover, coverage of (sectoral) collective agreements was very high, despite the low union density rate (estimated at $11 \%$ in 2009) due to the importance of administrative extensions which widened the reach of collective agreements beyond the signatory parties to all firms and workers in a sector. ${ }^{5}$

For an extension to be issued a specific request needed to be made to the government by either the employer association or the trade union (or both), with respect to a new or a revised collective agreement (in the latter case, the revision would be mostly about the updating of the minimum wages for workers of different occupations and job levels - Martins (2014)). The government would then assess the economic and social desirability of a potential extension, partly following on an empirical analysis of the number of workers potentially affected (in terms of increased salaries), while allowing other firms to present arguments against the potential extension. While this procedure had a tendency to delay the issuance of extensions by several months, the positive outcome of this procedure was virtually never in doubt, resulting in the extension of almost all collective agreements. To promote fully a level-playing field, extensions entered into force retro-actively, at the same time as the underlying collective agreements for the signatory parties. This led to backdated wage increases to workers not initially covered in the collective agreements, i.e. non unionised workers or unionised workers employed by firms not members of subscribing employer associations.

Due to the low levels of membership of the social partners (in particular the unions), extensions played a key role in supporting high and stable collective bargaining coverage in Portugal and effectively removed the scope for low-wage competition between affiliated and non-affiliated firms in each sector. Given the high level of unemployment and the need for restoring

\footnotetext{
${ }^{5}$ In the absence of extensions, the "double affiliation principle” applies. See footnote 2 for details.
} 
international competiveness, extensions were increasingly seen as a source of downward wage rigidity particularly in smaller, younger, typically less productive firms, who were generally not represented in the collective bargaining process. The low affiliation rates of the social partners thus not only increased the economic importance of coverage extensions, but also raised concerns that collectively agreed wage floors did not reflect appropriate conditions for nonaffiliated firms.

To address concerns about the role of administrative extensions for wage adjustment, the government that took office in June 2011 temporarily suspended the issuance of extensions with immediate effect while preparing a reform about the procedures in relation to extensions. This decision was made in the context of the structural reform package agreed between Portugal and its “troika” (EU, ECB and IMF). This package included a provision about collective bargaining (“define clear criteria to be followed for the extension of collective agreements", including "the representativeness of the negotiating organisations and the implications of the extension for the competitive position of non-affiliated firms”). ${ }^{6}$ The ensuing 2012 labor law reform reintroduced and revised extension procedures in two important ways. The first was to subject extensions to representativeness criteria. This entailed that extensions were made conditional on the employer association representing firms that together account for $50 \%$ of the workforce of the relevant sector. The second change was that extensions henceforth entered into force at the date of the administrative decision on the extension rather than the entry-into-force date of the collective agreement itself-in other words, retroactivity would no longer apply.

Given the low density of employer association membership, this led to concerns that the $50 \%$ representativeness criteria were too strict. Figure 2 documents the degree of representativeness of sectoral collective agreements signed between September 2010 and August 2011 in terms of the workforce in firms that are affiliated to an employer association, as a share of the total

\footnotetext{
${ }^{6}$ The full passage reads "Define clear criteria to be followed for the extension of collective agreements and commit to them. The representativeness of the negotiating organisations and the implications of the extension for the competitive position of nonaffiliated firms will have to be among these criteria. The representativeness of negotiating organisations will be assessed on the basis of both quantitative and qualitative indicators. To that purpose, the Government will charge the national statistical authority to do a survey to collect data on the representativeness of social partners on both sides of industry. Draft legislation defining criteria for extension and modalities for their implementation will be prepared by Q2-2012”. The full text of the original version of the memorandum of understanding is available at http://ec.europa.eu/economy finance/eu_borrower/mou/2011-0518-mou-portugal_en.pdf (page 24).
} 
workforce of the sector. The figure shows that in the large majority of collective agreements the share of the workforce in affiliated firms fell well short of the $50 \%$ threshold adopted.

Figure 2. The representativeness of collective agreements

Share of sectoral workers in firms that are affiliated with employer associations for collective agreements signed between October 2010 and August 2011

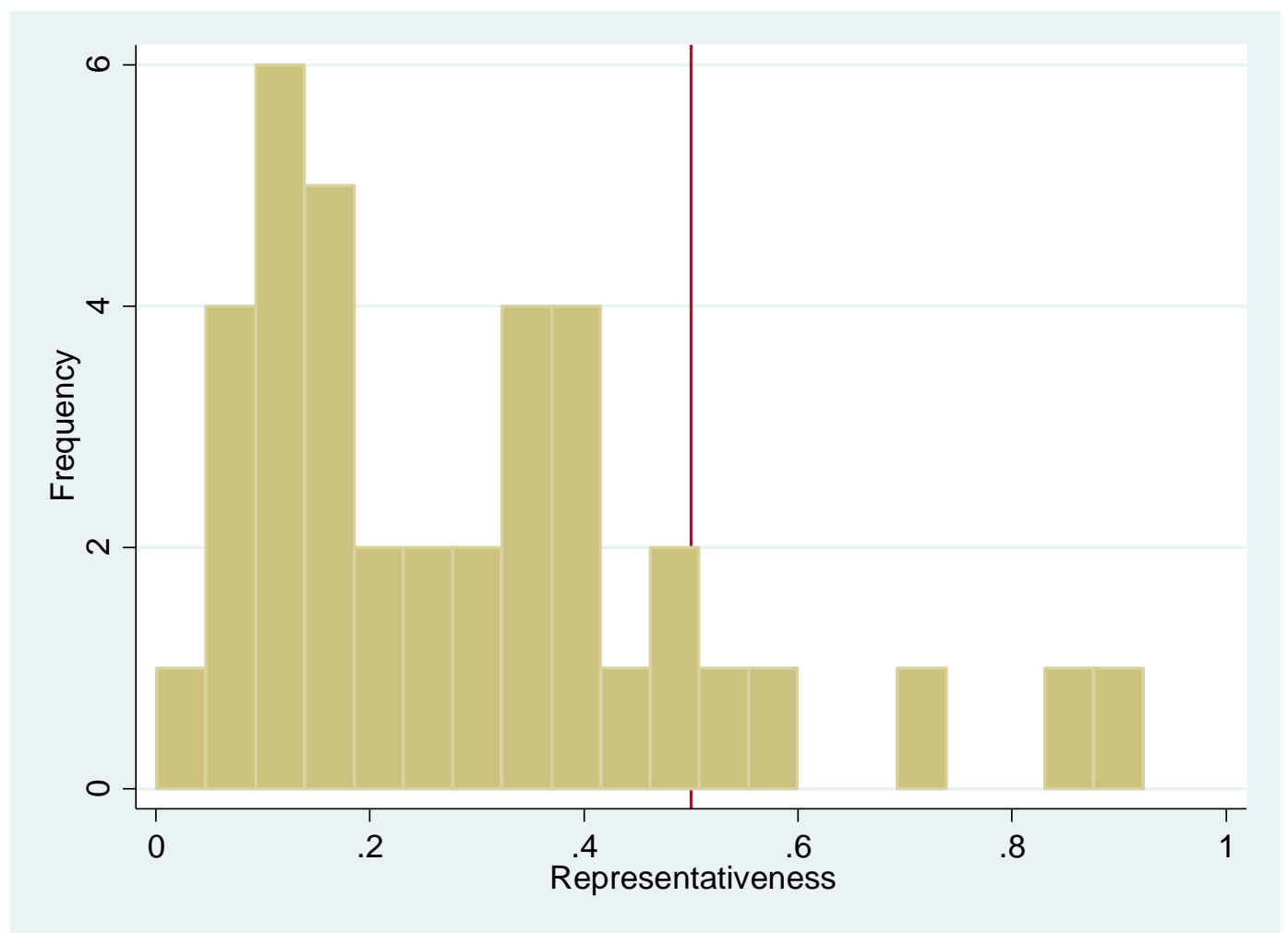

Source: Ministry of Labor (DGERT) and Quadros de Pessoal, authors’ calculations.

Consequently, the re-introduction of extensions in 2012 only led to a modest pick-up in the number of administrative extensions as shown in Figure 3. In part this reflected the sharp decline in the number of new or revised collective agreements concluded at the sectoral level, which in turn is also likely to have reflected, at least to some extent, the more stringent extension regime, as it may have reduced the benefits from collective agreements for employer associations.

Figure 3. Number of sectoral collective agreements and extensions, 2000-2015 


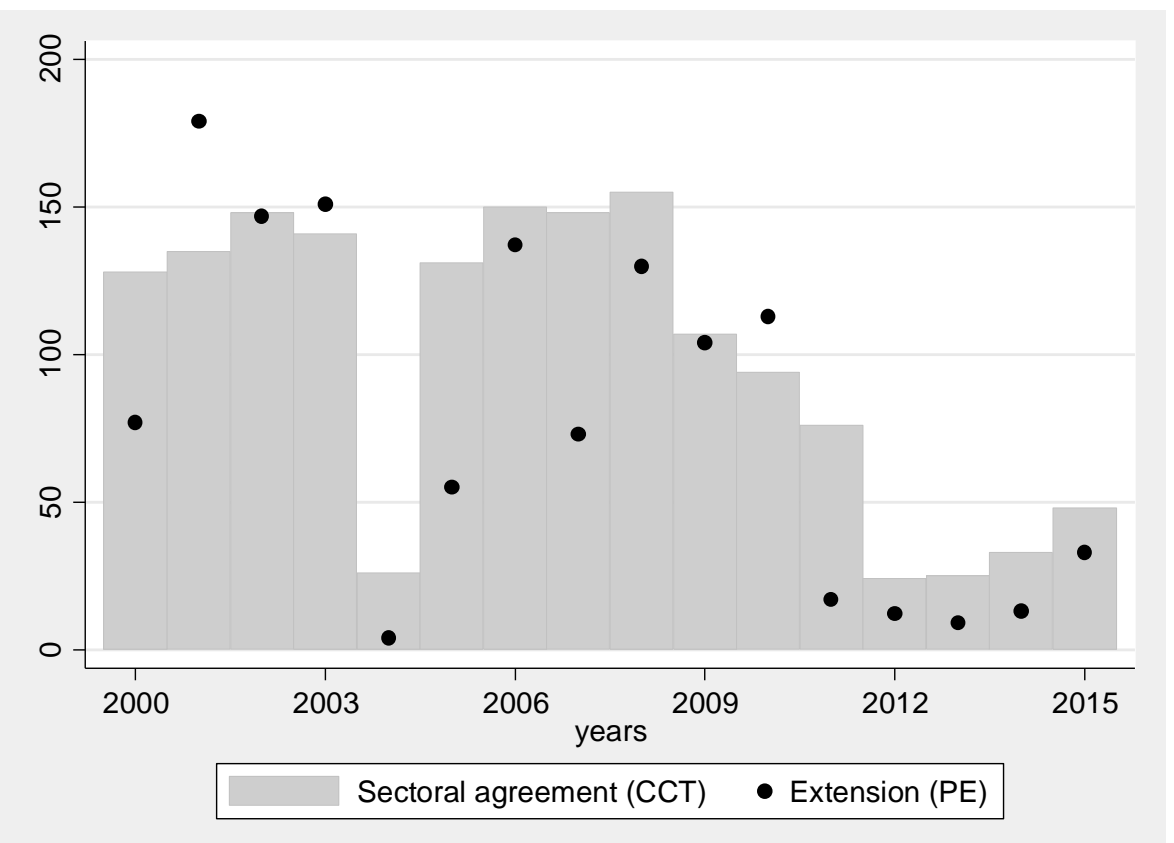

Source: Ministry of Labor (DGERT), authors’ calculations.

Lingering concerns about the stringency of representativeness criteria in relation to extensions resulted in another reform of the Labor Code in July 2014, after the end of the adjustment program, which introduced an alternative representativeness criterion, met if more than $30 \%$ of firms affiliated to a signatory employer association consisted of small or medium-sized enterprises. In the present context, small and medium sized enterprises are defined as firms employing less than 250 employees. Since this is likely to be the case for the large majority of employer associations, this largely represented a return to the situation pre-2011. This has resulted in a modest pick-up of the number of extensions issued in 2015 (Figure 3).

\section{Methodology}

\section{A. The "natural" experiment}

In order to analyse the causal effect of coverage extensions, this paper makes use of the natural experiment that resulted from the decision of the government that took office on 21 June 2011 to immediately suspend the extension of collective agreements. Importantly, due to the usual administrative delay associated with the extension of collective agreements, a substantial number of collective agreements had been signed before the new government took office on 21 
June 2011 but were not extended or, in a limited number of cases, had their extension considerably delayed (to the second half of 2012 or later).

As shown in Figure 4, this created a sharp discontinuity around February 2011 in the probability that a collective agreement was extended in the 12 months following the conclusion of a collective agreement. More specifically, the figure displays the probability that collective agreements published in each of the weeks before or after 1 March 2011 are extended in 2011. Until 24 January 2011, about six weeks before the cutoff date, all collective agreements were extended during the subsequent twelve months. In the period from 24 January 2011 to 28 February 2011 some collective agreements were extended, but not all as was the case before. From 1 March 2011 until 20 June 2011, no collective agreements were extended during the subsequent twelve months.

Figure 4. The probability that a collective agreement is extended

Weeks from 1 March 2011 (8 October 2010 - 20 June 2011)

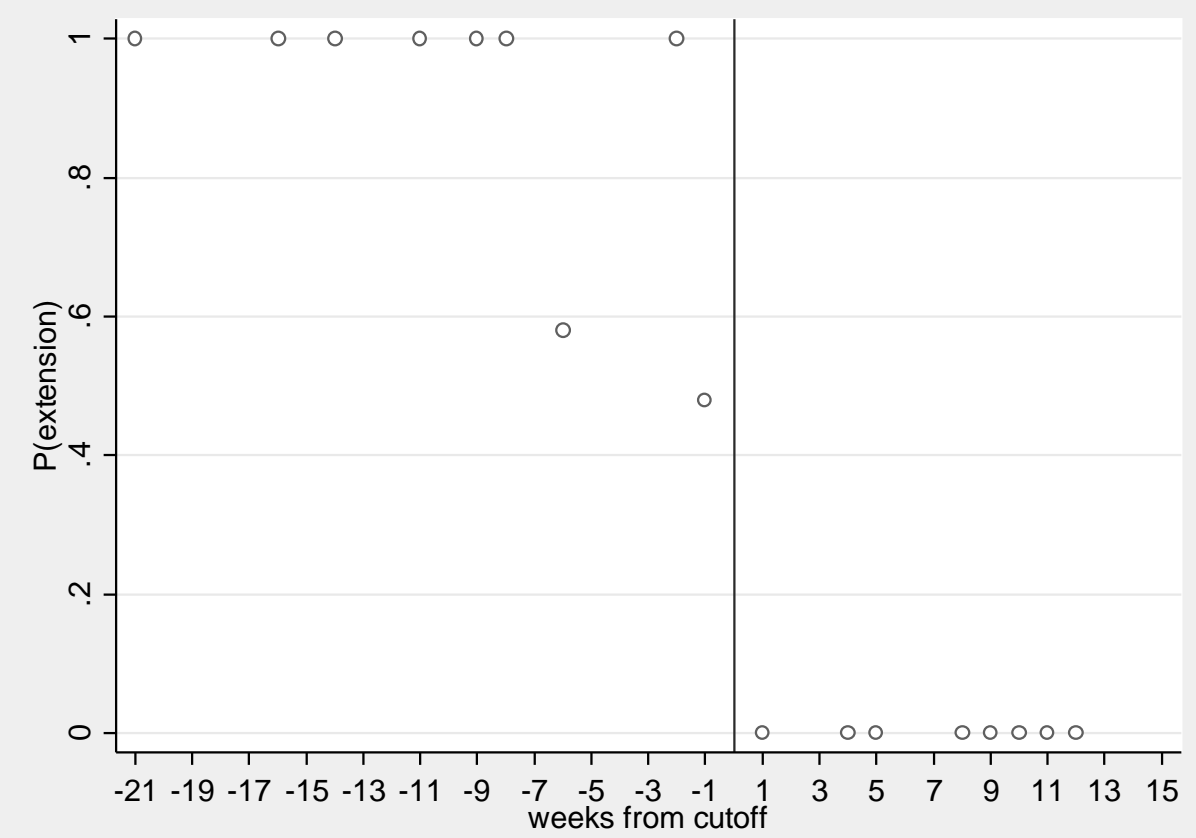

Source: Ministry of Labor (DGERT), authors’ calculations. 
Moreover, the decision of the new government to suspend the extension of collective agreements was unexpected and hence could not be anticipated by the trade unions and employer associations conducting the bargaining (a process that can last six months or more). In fact, in February or even in March 2011, there was no public information regarding the April $6^{\text {th }}$ bailout request, the May $17^{\text {th }}$ bailout package, the June $5^{\text {th }}$ elections (a full legislature would come to an end only in 2013) nor the new policy on extensions introduced by the government that took office in June $21^{\text {st }}$.

This means that insofar as one focuses on a short window around 1 March 2011, it is unlikely that there are systematic differences in the characteristics of workers and firms covered by collective agreements in the period just before the new government took office and that were extended and the characteristics of workers and firms covered by collective agreements in the period just after the new government took office and that were not extended. While this is uncontroversial in Portugal, it is important for the present paper as it determines the validity of the "natural" experiment for analyzing the causal impact of extensions. This is discussed in detail in Section B.

\section{B. Regression discontinuity design (RDD)}

The sharp and unanticipated decline in the probability that a collective agreement is extended in early 2011 is used to analyse the impact of extensions by means of a regression discontinuity design (RDD). The intuition of RDD is that the outcomes of firms and workers covered by collective agreements signed just before 1 March 2011 provide a good counterfactual for those of firms and workers where a collective agreement has been signed just after 1 March but then is not extended. The main advantage of RDD compared with other quasi-experimental estimators is that it relies on relatively weak assumptions and that these are testable in the same way as in a randomised experiment (Hahn, Todd and Van der Klaauw, 2001; Lee and Lemieux, 2010).

Since there is some variation in the administrative delay associated with the extension of agreements, the probability of extension does not fall from one to zero from one week to the next (see Figure 4). In order to allow using a sharp design, we drop the two agreements signed 
between 24 January and 28 February of 2011 that were not extended. In this case, all agreements signed before 1 March 2011 were extended and all those signed after were not. ${ }^{7}$

Formally, the sharp RDD can be described by the following model:

(1) $y_{i}=\alpha+\delta D_{i}+\gamma f\left(t_{i}-T\right)+\theta X_{i}+v_{i}$

where y refers to the outcome variable of interest, e.g. the growth rate of employment for collective agreement $i, D_{i}$ a treatment dummy that is equal to one if an agreement $i$ is extended in 2011 and zero otherwise (in practice, this means that the dummy takes value zero from 1 March 2011 onwards), $f($.$) a function that controls for the independent effect of relative time t$ on both sides of the threshold $T$ (i.e. time until or since the time threshold), and $\mathrm{X}_{\mathrm{i}}$ is a set of controls (discussed in Section C below).

An alternative possibility is to make use of a fuzzy RDD that explicitly takes account of the non-fully sharp decline in the probability of extension during the period 24 January 2011 to 28 February 2011, given the two data points mentioned above. Formally, the fuzzy RDD can be described by an outcome equation and a treatment equation. The treatment equation models the probability that a collective agreement is extended conditional on relative time as a function of a constant $(\alpha)$, a dummy $\left(T_{i}\right)$ that is equal to one from the date after which the probability of an extension is zero and a function that controls for the independent effect of relative time on both sides of the threshold $(f()$.$) :$

(2a) $D_{i}=\alpha+\delta T_{i}+\gamma f\left(t_{i}-T\right)+\theta X_{i}+\varepsilon_{i}$

The outcome equation in turn models the outcome variable of interest $(y)$ as a function of a constant $(\alpha)$, the predicted probability that the agreement is extended $\widehat{D}$ and a function that controls for the independent effect of time on both sides of the threshold $(f()$.$) , as in (2a):$

\footnotetext{
${ }^{7}$ An alternative option would be to focus on agreements signed just before 24 January 2011 and those signed just after 28 February 2011. However, this would unduly restrict the size of the sample.
} 
(2b) $y_{i}=\alpha+\tau \widehat{D}_{i}+\gamma f\left(t_{i}-T\right)+\theta X_{i}+v_{i}$

The outcome and treatment equations are estimated with 2SLS using the same estimation sample for the treatment and outcome equations. ${ }^{8}$

In practice, we pool the data across affiliated and non-affiliated firms, that is, we stack them up for each collective agreement. We then perform two exercises. First, we estimate the impact of extensions on total employment growth across firms while controlling for affiliation status. Second, in order to analyze the differential effects of extensions on firms that are affiliated to an employer association versus those that are not, we add an interaction between the treatment dummy and the dummy for affiliation status, allow for different relative time effects across affiliation-status groups, and, as before, also control for the independent effect of affiliation status. Standard errors correct for heteroskedasticity and are clustered by agreement and agreement date as suggested by Card and Lee (2008).

Controlling for relative time effects is key in the present context for two main reasons. First, since the dependent variable is typically measured from October 2010 to October 2011, the share of the year to which firms are exposed to extensions depends on their timing. An agreement that is extended later necessarily has a smaller time period to generate effects than one that is extended earlier. Second, economic conditions may affect the timing of agreements as well as their actual contents. For these reasons, firm performance is likely to depend on relative time. In our analysis, relative time effects are assumed to be either linear or quadratic and are allowed to differ between the two sides of the threshold. ${ }^{9}$

Regressions are weighted by the number of employees in 2010 in order to obtain the average effect of extensions on total employment (rather than the average effect of extensions on firmlevel employment that would be obtained if no weights were used).

\footnotetext{
${ }^{8}$ Note that even though the treatment equation represents a limited dependent variable model, there is no need to make use of probit or logit model since the model is completely unrestricted around the threshold (Lee and Lemieux, 2010).

${ }^{9}$ Given the small sample, we will mainly focus on (potentially asymmetric) linear relative time effects.
} 


\section{Validity}

The validity of our RDD hinges on the assumption that the decision of the new government to suspend the extension of collective agreements was unexpected and hence could not be anticipated by the social partners.

If, on the contrary, the suspension of extensions was anticipated, one would expect this to, first of all, affect the incentives for concluding an agreement and hence the frequency of observing new or revised collective agreements. Figure 5 plots the number of agreements in each week during the period October 2010 to June 2011. It does not find that the average number of collective agreements published in each week declined after 1 March 2011. The average number of agreements per week is even slightly higher after March 2011 than in the period that preceded it. $^{10}$

Figure 5. The number of collective agreements over time

Weeks from 1 March 2011 (8 October 2010 - 20 June 2011)

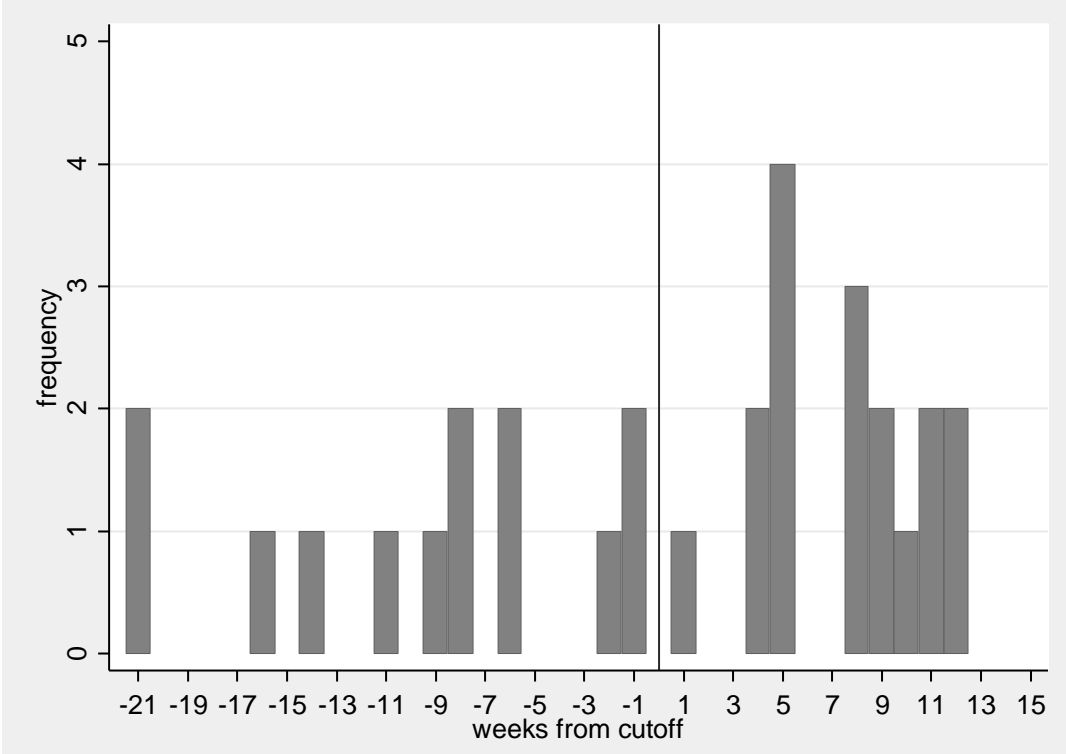

Source: Ministry of Labor (DGERT), author's calculations.

\footnotetext{
${ }^{10}$ Given the limited number of collective agreements in each week, a formal test on the continuity of the density of agreements around the threshold does not seem to be informative.
} 
Anticipation effects may also be reflected in the contents of the agreements and their composition across different types of firms and workers. In order to check whether there are any systematic differences between agreements signed just before and after 1 March 2011, we conducted a series of balancing tests which assess whether there are discontinuities along a variety of different dimensions across the threshold. In practical terms, this involves estimating equation (1) using a number of pre-determined variables in our dataset as the dependent variable (see the next section for more information on our data). These are respectively the degree of representativeness (the share of the sector workforce in affiliated firms), the pre-reform employment growth rate (2009-2010), the size of the agreement in terms of the log number of employees potentially covered, log average firm size (in terms of employment), log average hourly wage, log median hourly wage, export intensity (exports as share of revenue), and log labor productivity (in terms of revenue per worker). The balancing tests control for linear relative time effects or quadratic relative time effects and are conducted for the pooled sample as well as separately by affiliation status.

The results in Table 1 suggest that for some variables there are statistically significant differences between the two groups. Given the small number of agreements used in the present context and the large number of variables considered in these balancing tests this may not be surprising. This may imply that the natural experiment that we are exploiting does not provide the equivalent of a randomized experiment. In light of this, we perform the regression analysis including additional controls to make the groups more comparable. Specifically, in order to take account of systematic differences in the pre-reform employment growth rate we allow explicitly for differential trends by focusing on the change in the growth rate of employment. Moreover, we include all other variables as controls for which systematic differences are observed in our analysis (e.g. average firm size, average export intensity). 
Table 1. Balancing tests

\begin{tabular}{|c|c|c|c|c|c|c|}
\hline \multirow[b]{2}{*}{ Balancing variables } & \multicolumn{2}{|c|}{ All } & \multicolumn{2}{|c|}{ Non-affiliated } & \multicolumn{2}{|c|}{ Affiliated } \\
\hline & $\begin{array}{l}(1) \\
\text { linear }\end{array}$ & $\begin{array}{c}\text { (2) } \\
\text { quadratic }\end{array}$ & $\begin{array}{l}\text { (3) } \\
\text { linear }\end{array}$ & $\begin{array}{c}\text { (4) } \\
\text { quadratic }\end{array}$ & $\begin{array}{l}\text { (3) } \\
\text { linear }\end{array}$ & $\begin{array}{c}\text { (4) } \\
\text { quadratic }\end{array}$ \\
\hline $\begin{array}{l}\text { Representativeness, } 2010 \\
\text { - share of workforce in afffiliated firms }\end{array}$ & $\begin{array}{c}0.0815 \\
(0.1143)\end{array}$ & $\begin{array}{l}-0.0080 \\
(0.0574)\end{array}$ & $\begin{array}{c}0.0923 \\
(0.1422)\end{array}$ & $\begin{array}{l}-0.0183 \\
(0.0617)\end{array}$ & $\begin{array}{c}0.0220 \\
(0.0695)\end{array}$ & $\begin{array}{c}0.0303 \\
(0.0510)\end{array}$ \\
\hline Employment growth, 2009-2010 & $\begin{array}{c}0.0865 \\
(0.0155) \\
* * *\end{array}$ & $\begin{array}{c}0.0975 \\
(0.0080) \\
* * *\end{array}$ & $\begin{array}{c}0.0953 \\
(0.0195) \\
* * *\end{array}$ & $\begin{array}{c}0.1045 \\
(0.0106) \\
* * *\end{array}$ & $\begin{array}{c}0.0813 \\
(0.0099) \\
* * *\end{array}$ & $\begin{array}{c}0.0844 \\
(0.0076) \\
* * *\end{array}$ \\
\hline Log employment, 2010 & $\begin{array}{l}-0.2195 \\
(0.6026)\end{array}$ & $\begin{array}{l}-0.1584 \\
(0.6073)\end{array}$ & $\begin{array}{l}-0.4327 \\
(0.6009)\end{array}$ & $\begin{array}{r}-0.3626 \\
(0.6273)\end{array}$ & $\begin{array}{c}0.5093 \\
(0.7890)\end{array}$ & $\begin{array}{c}0.1547 \\
(0.5082)\end{array}$ \\
\hline $\begin{array}{l}\text { Log average firm size, } 2010 \\
\text { - number of workers per firm }\end{array}$ & $\begin{array}{c}-1.2418 \\
(0.3004) \\
* * *\end{array}$ & $\begin{array}{c}-1.4115 \\
(0.1840) \\
* * *\end{array}$ & $\begin{array}{c}-1.2439 \\
(0.2429) \\
* * *\end{array}$ & $\begin{array}{c}-1.3098 \\
(0.2017) \\
* * *\end{array}$ & $\begin{array}{c}-1.5805 \\
(0.2265) \\
* * *\end{array}$ & $\begin{array}{c}-1.6135 \\
(0.1765) \\
* * *\end{array}$ \\
\hline $\begin{array}{l}\text { Log average wage, } 2010 \\
\text { - within job title and year }\end{array}$ & $\begin{array}{l}-0.0510 \\
(0.0870)\end{array}$ & $\begin{array}{l}-0.0812 \\
(0.0956)\end{array}$ & $\begin{array}{l}-0.0530 \\
(0.0852)\end{array}$ & $\begin{array}{l}-0.0603 \\
(0.0875)\end{array}$ & $\begin{array}{l}-0.1147 \\
(0.0901)\end{array}$ & $\begin{array}{l}-0.1120 \\
(0.0758)\end{array}$ \\
\hline $\begin{array}{l}\text { Log median wage, } 2010 \\
\text { - within job title and year }\end{array}$ & $\begin{array}{c}0.0040 \\
(0.0764)\end{array}$ & $\begin{array}{l}-0.0092 \\
(0.0828)\end{array}$ & $\begin{array}{l}-0.0127 \\
(0.0775)\end{array}$ & $\begin{array}{l}-0.0059 \\
(0.0781)\end{array}$ & $\begin{array}{l}-0.0243 \\
(0.0824)\end{array}$ & $\begin{array}{l}-0.0035 \\
(0.0605)\end{array}$ \\
\hline Export intensity, 2010 & $\begin{array}{c}-0.4642 \\
(0.0523) \\
* * *\end{array}$ & $\begin{array}{c}-0.4553 \\
(0.0494) \\
* * *\end{array}$ & $\begin{array}{c}-0.4072 \\
(0.0579) \\
* * *\end{array}$ & $\begin{array}{c}-0.3808 \\
(0.0583) \\
* * *\end{array}$ & $\begin{array}{c}-0.5818 \\
(0.0466) \\
* * *\end{array}$ & $\begin{array}{c}-0.6151 \\
(0.0264) \\
* * *\end{array}$ \\
\hline Log labour productivity, 2010 & $\begin{array}{c}0.1753 \\
(0.4604)\end{array}$ & $\begin{array}{l}-0.0735 \\
(0.5252)\end{array}$ & $\begin{array}{c}0.2313 \\
(0.4727)\end{array}$ & $\begin{array}{c}0.0320 \\
(0.5360)\end{array}$ & $\begin{array}{l}-0.2217 \\
(0.3814)\end{array}$ & $\begin{array}{l}-0.1636 \\
(0.2627)\end{array}$ \\
\hline
\end{tabular}

The estimates reported correspond to the coefficients of the extension dummy in equation (1). Regressions are weighted by the number of employees in 2010. Standard errors are robust and clustered by collective agreement and signature date. $*, * *, * * *$ refer to statistical significance levels of $10 \%, 5 \%$ and $1 \%$ respectively.

\section{DATA AND IMPLEMENTATION}

\section{A. Administrative personnel records (Quadros de Pessoal)}

The main data in this paper are drawn from administrative Personnel Records (Quadros de Pessoal, henceforth $Q P$ ), a matched employer-employee panel that covers the universe of firms and workers in the private sector in Portugal (see Cardoso and Portugal, 2005, Martins, 2009a, and Martins et al, 2012, for earlier papers using QP). Given our goals, we focus on the period 2009-2013: information on workers refers to October of each year, while information on firms refers to the full year. $Q P$ provides rich information on workers and firms. Particularly important for the present purposes is information on the applicable collective agreement for each worker and on employer association membership of firms, i.e. whether they are a member and if so of which one, the latter available only for 2010. Consequently, we analyse the role of affiliation status for the impact of extensions based on their affiliation in the last year before the reform took place. This implies that we focus on firms that were present in 2010, as well as all their workers, but cannot consider new firms. For the present purposes, we do not require any 
information on employer association membership in the subsequent years. Firms that are covered by firm- and holding-level agreements are excluded from the analysis.

\section{B. Information on collective agreements and extensions (DGERT)}

Information on collective agreements and their possible extensions is publicly available from the Ministry of Labor (DGERT) website. ${ }^{11}$ The resulting dataset includes information on the publication dates of collective agreements and, if applicable, of their extensions, the signatory employer associations and trade unions as well as the economic activities (and regions and or occupations, if applicable) covered by the agreement.

The dataset used for the empirical analysis consists of 38 collective agreements signed over the period October 2010 to August 2011 (see the Annex for details). Together these account for approximately $20 \%$ of the workforce in the private sector. In the empirical analysis, we mainly focus on the 31 agreements that were signed between 8 October 2011 and 20 June 2011. The reason for limiting the scope to agreements until 20 June 2011 is that the extension procedure was suspended when the new government took office in 21 June $2011 .^{12}$ This gives us a 15week window from 1 March 2011 to 20 June 2011 during which 18 new or revised agreements were signed that were not extended during the subsequent 12 months. This was preceded by a 5-week transition period during which most agreements that were signed were subsequently extended except but not all (24 January 2011 - 28 February 2011). The period from 8 October 2010 to 24 January 2011 corresponds to a 15-week window during which all new or revised agreements were subsequently extended. During the period from 8 October 2010 to 28 February 201113 new or revised agreements were signed.

\footnotetext{
${ }^{11}$ http://bte.gep.msess.gov.pt/

${ }^{12}$ While this decision was not publicized and unlikely to have had a major impact on collective bargaining in the following weeks, we feel it is more prudent to limit ourselves to agreements that were signed before the new government took place. However, as will be shown below, the analysis is robust to adding these agreements to the analysis.
} 


\subsection{Combining the information into a semi-aggregated dataset}

For the present purposes, we construct a dataset with information on employment, wages, sales, exports and productivity (sales per worker) by agreement, year, and membership status, thus combining information from $Q P$ with information from collective agreements (DGERT). Unfortunately, linking the two sources of information is not straightforward in practice since the agreement codes in $Q P$ do not necessarily correspond to those used by DGERT. We proceeded as follows. First, since workers in each firm may be covered by more than one agreement, we focus on the agreement that represents the largest share of workers in the firm. Second, we use the name of the employer associations in which affiliated firms are affiliated to link collective agreements in $Q P$ and DGERT. Third, we extend the linking between the two collective agreement codes (QP and DGERT) to non-affiliated firms. In other words, we establish the domain of each collective agreement in terms of firm identifiers, first using 2010 data (for which we have employer affiliation information) and then the remaining years too. Fourth, we collapse the firm-level data by year, agreement and employer association membership status. This yields a dataset with 76 observations (38 agreements for each affiliation status group).

\section{RESULTS ON EMPLOYMENT GROWTH}

\section{A. Overall effects of extensions}

The results on the impact of extensions on employment growth relative to the pre-reform trend across all firms, irrespective of their membership status, are reported in Table 2. It shows the results based on both the fuzzy and the sharp RDD under the assumption of either linear or quadratic relative time effects. The results based on the sharp RDD using a linear specification are visualized in Figure $6 .{ }^{13}$

\footnotetext{
${ }^{13}$ For ease of presentation, the results presented in Figure 6 do not include any controls apart from affiliation status and relative time effects.
} 
Table 2. The effects of extensions, all firms

Panel A. Employment growth, p.p., 2010-2011 ( $\left.\Delta \mathrm{E}_{\mathrm{t}}\right)$

\begin{tabular}{lcc|cc}
\hline & \multicolumn{2}{c|}{ Fuzzy } & \multicolumn{2}{c}{ Sharp } \\
& $(1)$ & $(2)$ & $(1)$ & $(2)$ \\
\hline & & & & \\
Treatment dummy & -0.0953 & -0.0500 & -0.0578 & -0.0420 \\
& $(0.0446)$ & $(0.0591)$ & $(0.0262)$ & $(0.0262)$ \\
& $* *$ & & $* *$ & \\
Constant & -0.1042 & -0.1358 & -0.1226 & -0.1293 \\
& $(0.0388)$ & $(0.0274)$ & $(0.0313)$ & $(0.0236)$ \\
& $* *$ & $* * *$ & $* * *$ & $* * *$ \\
Relative time effects & Linear & Quadratic & Linear & Quadratic \\
& & & & \\
Observations & 62 & 62 & 58 & 58 \\
R-squared & 0.3976 & 0.4037 & 0.4290 & 0.4359 \\
\hline \hline
\end{tabular}

Panel B. Change in employment growth, p.p., $\left(\Delta \mathrm{E}_{\mathrm{t}}-\Delta \mathrm{E}_{\mathrm{t}-1}\right)$

\begin{tabular}{lcc|cc|}
\hline & \multicolumn{2}{c|}{ Fuzzy } & \multicolumn{2}{c}{ Sharp } \\
& $(1)$ & $(2)$ & $(1)$ & $(2)$ \\
\hline & & & & \\
Treatment dummy & -0.1574 & -0.1472 & -0.1022 & -0.1035 \\
& $(0.0548)$ & $(0.0709)$ & $(0.0301)$ & $(0.0295)$ \\
& $* * *$ & $* *$ & $* *$ & $* * *$ \\
Constant & -0.1950 & -0.1985 & -0.2238 & -0.1926 \\
& $(0.0380)$ & $(0.0360)$ & $(0.0279)$ & $(0.0247)$ \\
& $* * *$ & $* * *$ & $* * *$ & $* * *$ \\
& & & & \\
Relative time effects & Linear & Quadratic & Linear & Quadratic \\
& & & & \\
Observations & 62 & 62 & 58 & 58 \\
R-squared & 0.6579 & 0.6581 & 0.6809 & 0.6958 \\
\hline \hline
\end{tabular}

Regressions are weighted by the number of employees in 2010. They include controls for log average firm size, export intensity and affiliation status. Standard errors are robust and clustered by collective agreement and signature date. *, **, *** refer to statistical significance levels of $10 \%, 5 \%$ and $1 \%$ respectively.

Authors' calculations based on QP and DGERT data. 
According to the results, extensions have an adverse and statistically significant impact on employment growth. The results tend to be qualitatively similar whether a fuzzy or a sharp setup is used, whether linear or quadratic controls for relative time are included and whether the pre-reform trend is controlled for or not. ${ }^{14}$ The impact of extensions on employment growth is potentially large, ranging from 5 to 10 percentage points depending on the specification. These large effects are likely to reflect at least in part the specific context during which the natural experiment took place, namely that of the 2010Q4-2012Q4 recession hitting firms still recovering from the global financial crisis. Because the need for adjusting working conditions was presumably greater under such circumstances, extensions may have had a larger adverse impact on employment than they would have had in normal times. Furthermore, as discussed in Section 5.3, the retro-active entry-into-force of extensions in a context where many firms are liquidity-constrained is found to have exacerbated the negative employment effects found here.

\footnotetext{
${ }^{14}$ Note, however, that the coefficients lose statistical significance when controlling for quadratic relative time effects when focusing on employment growth but remain largely unchanged when focusing on the change in employment growth.
} 
Figure 6. The overall effects of extensions on employment growth

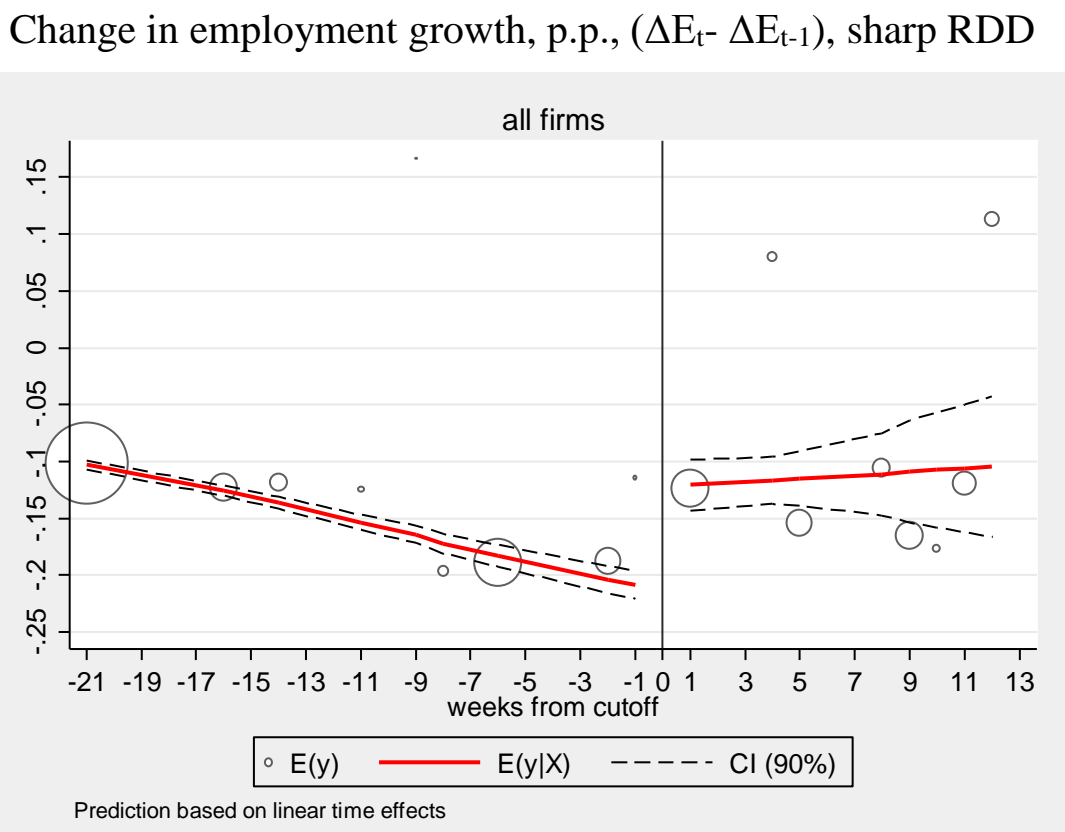

The figure presents the estimated change in the growth rate of employment by collective agreement publication week, as measured from the threshold date of 1 March 2011 (week 0). The results are estimated from a sharp RDD using employment weights. The size of the circles is proportional to the employment of the corresponding collective agreement(s). Standard errors are robust and clustered by collective agreement and signature date. * **, *** refer to statistical significance levels of $10 \%, 5 \%$ and $1 \%$ respectively.

Authors' calculations based on QP and DGERT data.

The results are robust to a variety of different specifications. Focusing on the specification with linear relative time effects, Table 3 compares the baseline results with alternative specifications or samples, in the following order. "Controls" includes only affiliation status as control and not average firm size and export intensity as in the baseline specification. "Bandwidth" extends the observation window by including agreements signed after the new government took office in June 2011 to the end of August 2011. "Falsification" assesses whether there is a discontinuity when using a placebo date that evenly splits the number of agreements in the post-reform period (March - August) on each side of a fictional threshold (around the middle of May). The results indicate that excluding the controls and extending the bandwidth does not qualitatively change the results relative to the baseline. The falsification test does not point to any discontinuities in employment growth around the fictional reform date. 
Table 3. Sensitivity analysis, all firms

Panel A. Fuzzy RDD

\begin{tabular}{l|cccc|cccc}
\hline & \multicolumn{5}{|c|}{ Employment growth } & \multicolumn{5}{c}{ Change in employment growth } \\
& Baseline & Controls & Bandwidth & Falsification & Baseline & Controls & Bandwidth Falsification \\
\hline \multirow{3}{*}{ Treatment dummy } & & & & & & & & \\
& -0.0953 & -0.0511 & -0.0976 & -0.0345 & -0.1574 & -0.1217 & -0.1540 & -0.0345 \\
& $(0.0446)$ & $(0.0163)$ & $(0.0566)$ & $(0.0556)$ & $(0.0548)$ & $(0.0189)$ & $(0.0523)$ & $(0.0556)$ \\
Constant & $* *$ & $* * *$ & $*$ & & $* *$ & $* *$ & $* *$ & \\
& -0.1042 & -0.0963 & -0.1078 & -0.2129 & -0.1950 & -0.1350 & -0.1701 & -0.2129 \\
& $(0.0388)$ & $(0.0053)$ & $(0.0523)$ & $(0.0541)$ & $(0.0380)$ & $(0.0123)$ & $(0.0327)$ & $(0.0541)$ \\
Relative time effects & $* *$ & $* * *$ & $* *$ & $* * *$ & $* * *$ & $* * *$ & $* *$ & $* * *$ \\
Observations & Linear & Linear & Linear & Linear & Linear & Linear & Linear & Linear \\
R-squared & 62 & 62 & 76 & 46 & 62 & 62 & 76 & 46 \\
\hline \hline
\end{tabular}

Panel B. Sharp RDD

\begin{tabular}{l|cccc|cccc}
\hline & \multicolumn{5}{|c|}{ Employment growth } & \multicolumn{5}{c}{ Change in employment growth } \\
& Baseline & Controls & Bandwidth Falsification & Baseline & Controls & Bandwidth Falsification \\
\hline \multirow{4}{*}{ Treatment dummy } & & & & & & & & \\
& -0.0578 & -0.0603 & -0.0164 & -0.0345 & -0.1022 & -0.1169 & -0.0898 & -0.0345 \\
& $(0.0262)$ & $(0.0203)$ & $(0.0264)$ & $(0.0556)$ & $(0.0301)$ & $(0.0245)$ & $(0.0210)$ & $(0.0556)$ \\
Constant & $* *$ & $* * *$ & & & $* *$ & $* * *$ & $* * *$ & \\
& -0.1226 & -0.0891 & -0.1570 & -0.2129 & -0.2238 & -0.1352 & -0.2017 & -0.2129 \\
& $(0.0313)$ & $(0.0115)$ & $(0.0412)$ & $(0.0541)$ & $(0.0279)$ & $(0.0143)$ & $(0.0259)$ & $(0.0541)$ \\
Relative time effects & $* * *$ & $* * *$ & $* * *$ & $* * *$ & $* * *$ & $* * *$ & $* * *$ & $* * *$ \\
Observations & Linear & Linear & Linear & Linear & Linear & Linear & Linear & Linear \\
R-squared & 58 & 58 & 72 & 46 & 58 & 58 & 72 & 46 \\
\hline \hline
\end{tabular}

Regressions are weighted by the number of employees in 2010 and include controls for log average firm size, export intensity and affiliation status unless stated otherwise. Standard errors are robust and clustered by collective agreement and signature date. *, **, *** refer to statistical significance levels of $10 \%, 5 \%$ and $1 \%$ respectively. “Controls": affiliation status only; "bandwidth”: October 2010-August 2011; “Falsification”: placebo reform date (mid-May 2011) using agreements in post-reform period only (March 2011 - August 2011).

Authors' calculations based on QP and DGERT data.

\section{B. Effects of extensions by affiliation status}

In order to analyze the effects of extensions across firms that are or are not affiliated to an employer association, we now allow their effects to differ across firms that are and those that are not by adding an interaction term of the treatment dummy with affiliation status. The baseline results along with a number of sensitivity checks are reported in Table 4 . The results based on sharp RDD with linear relative time effects are visualized in Figure 7.

The results indicate that the adverse impact of extensions on employment growth tends to be concentrated among non-affiliated firms. This is the case for the majority of specifications reported, including for our preferred specifications that control for the pre-reform growth rate 
in employment. The fuzzy RDD results suggest that the impact of extensions is negative and statistically significant for non-affiliated firms, but positive and statistically significant for affiliated firms. Using the sharp RDD, the results are more mixed, with the results for employment growth suggesting that the effects are concentrated among affiliated firms and those for the change in employment growth that the effects are concentrated among nonaffiliated firms. ${ }^{15}$ Since we prefer the results that control for differences in the pre-reform growth rate in employment by focusing on the change in employment growth, we conclude that the negative effects of extensions are concentrated among non-affiliated firms. The sensitivity checks further suggest that the baseline results do not hinge on the inclusion of controls or the definition of the observation window. Moreover, the falsification test does not point at the presence of any significant discontinuities around the fictive threshold in the post-reform period.

\footnotetext{
${ }^{15}$ When focusing on the change in employment growth, extensions have a significant impact on both non-affiliated firms and affiliated firms, with their impact being about twice as large among non-affiliated firms as among affiliated firms. The effects among affiliated firms may indicate that some of these firms only increase the pay of their non-unionised workers once extensions are issued. Alternatively, these effects may reflect the increase in market power by affiliated firms and the subsequent reduction in output and employment to maximize profits.
} 
Figure 7. The effects of extensions by affiliation status

Change in employment growth, p.p., $\left(\Delta \mathrm{E}_{\mathrm{t}}-\Delta \mathrm{E}_{\mathrm{t}-1}\right)$
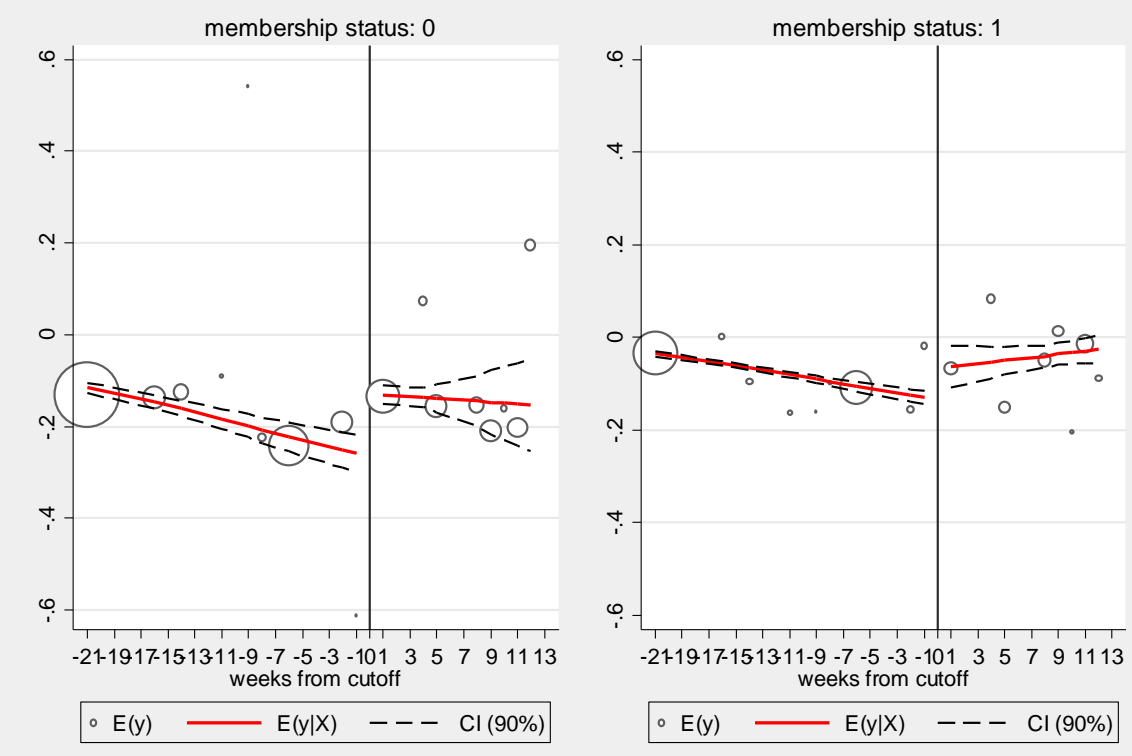

Predictions based on linear time effects

\begin{abstract}
"Membership status: 0" refers to non-affiliated firms; "Membership status: 1" refers to affiliated firms. The figure presents the estimated change in the growth rate of employment by collective agreement publication week, as measured from the threshold date of 1 March 2011 (week 0). The results are estimated from a sharp RDD using employment weights. The size of the circles is proportional to the employment of the corresponding collective agreement(s). Standard errors are robust and clustered by collective agreement and signature date. *, **, *** refer to statistical significance levels of $10 \%, 5 \%$ and $1 \%$ respectively.

These results are consistent with the view that affiliated firms can shape the use of extensions for their own benefit at the expense of non-affiliated outsiders. They also provide a first indication that representativeness matters since the wage floors negotiated in collective agreements appear to be less appropriate for affiliated firms than for non-affiliated firms. This suggests that the lack of representativeness of employer associations is a potentially important factor behind the adverse effect of extensions.
\end{abstract}


Table 4. Results by affiliation status

Panel A. Employment growth (2010-2011)

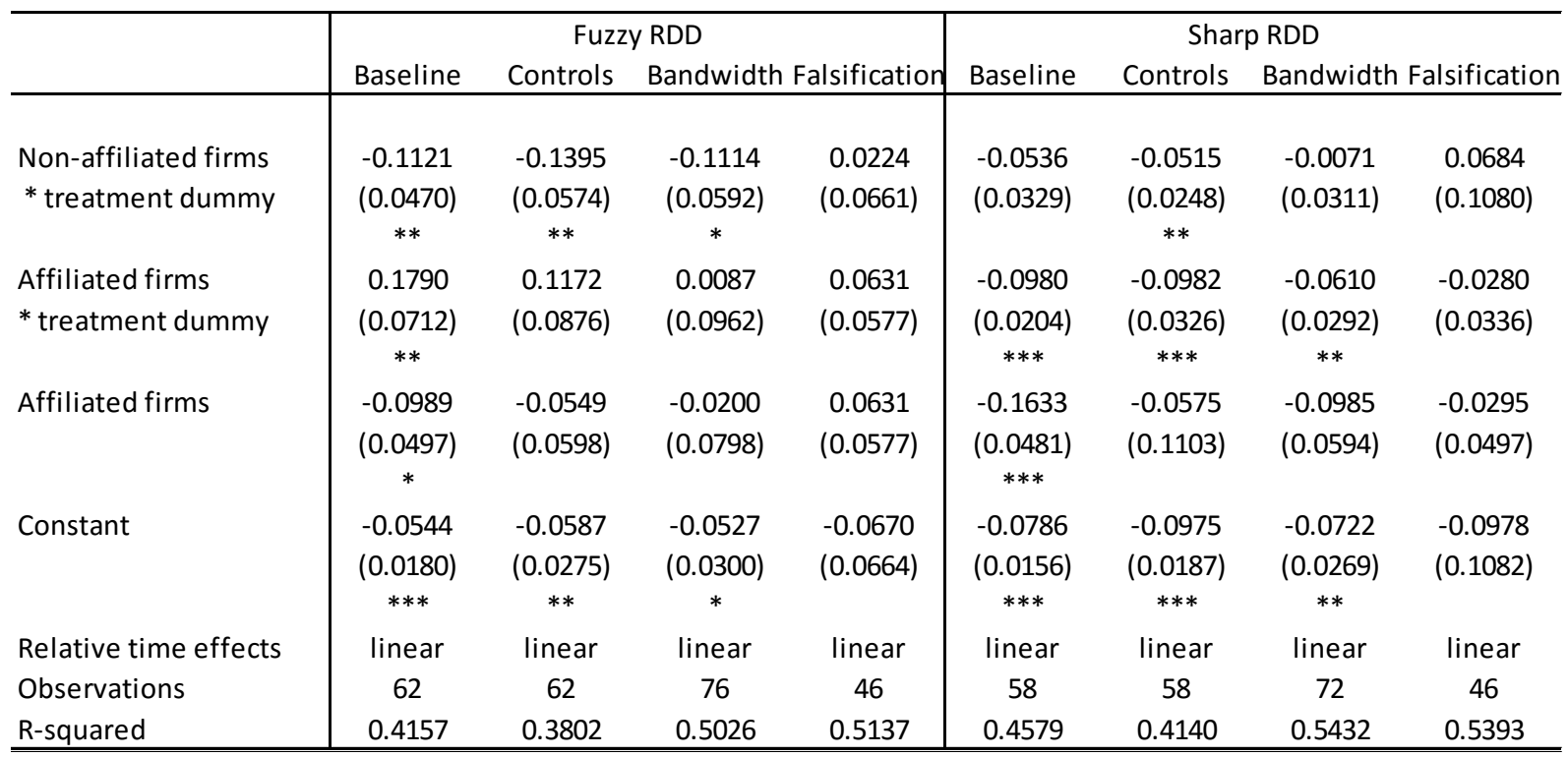

Panel B. Change in employment growth

\begin{tabular}{|c|c|c|c|c|c|c|c|c|}
\hline & \multicolumn{4}{|c|}{ Fuzzy RDD } & \multicolumn{4}{|c|}{ Sharp RDD } \\
\hline & Baseline & Controls & Bandwidt & alsification & Baseline & Controls & Bandwidth & alsification \\
\hline $\begin{array}{l}\text { Non-affiliated firms } \\
* \text { treatment dummy }\end{array}$ & $\begin{array}{c}-0.1787 \\
(0.0653) \\
* *\end{array}$ & $\begin{array}{c}-0.2446 \\
(0.1118) \\
* *\end{array}$ & $\begin{array}{c}-0.1706 \\
(0.0650) \\
* *\end{array}$ & $\begin{array}{l}-0.0370 \\
(0.0607)\end{array}$ & $\begin{array}{c}-0.1222 \\
(0.0428) \\
* * *\end{array}$ & $\begin{array}{c}-0.1309 \\
(0.0306) \\
* * *\end{array}$ & $\begin{array}{c}-0.0986 \\
(0.0309) \\
* * *\end{array}$ & $\begin{array}{l}-0.0337 \\
(0.0928)\end{array}$ \\
\hline $\begin{array}{l}\text { Affiliated firms } \\
* \text { treatment dummy }\end{array}$ & $\begin{array}{c}0.2565 \\
(0.0916) \\
* * *\end{array}$ & $\begin{array}{c}0.1080 \\
(0.1877)\end{array}$ & $\begin{array}{c}0.1798 \\
(0.0887) \\
*\end{array}$ & $\begin{array}{l}-0.0295 \\
(0.0497)\end{array}$ & $\begin{array}{c}-0.0512 \\
(0.0159) \\
* * *\end{array}$ & $\begin{array}{c}-0.0636 \\
(0.0317) \\
*\end{array}$ & $\begin{array}{c}-0.0681 \\
(0.0272) \\
* *\end{array}$ & $\begin{array}{l}-0.0216 \\
(0.0255)\end{array}$ \\
\hline Affiliated firms & $\begin{array}{c}0.0779 \\
(0.0265) \\
* * *\end{array}$ & $\begin{array}{c}0.1072 \\
(0.0411) \\
* *\end{array}$ & $\begin{array}{c}0.0707 \\
(0.0474)\end{array}$ & $\begin{array}{c}0.0380 \\
(0.1109)\end{array}$ & $\begin{array}{l}-0.0080 \\
(0.0273)\end{array}$ & $\begin{array}{c}0.0612 \\
(0.0309) \\
*\end{array}$ & $\begin{array}{c}0.0540 \\
(0.0442)\end{array}$ & $\begin{array}{c}0.0634 \\
(0.0984)\end{array}$ \\
\hline Constant & $\begin{array}{c}-0.0710 \\
(0.0163) \\
* * *\end{array}$ & $\begin{array}{l}-0.0814 \\
(0.0481)\end{array}$ & $\begin{array}{c}-0.0888 \\
(0.0210) \\
* * *\end{array}$ & $\begin{array}{c}-0.1138 \\
(0.0532) \\
* *\end{array}$ & $\begin{array}{c}-0.0865 \\
(0.0164) \\
* * *\end{array}$ & $\begin{array}{c}-0.1283 \\
(0.0181) \\
* * *\end{array}$ & $\begin{array}{c}-0.1113 \\
(0.0212) \\
* * *\end{array}$ & $\begin{array}{l}-0.1247 \\
(0.0870)\end{array}$ \\
\hline $\begin{array}{l}\text { Relative time effects } \\
\text { Observations }\end{array}$ & $\begin{array}{l}\text { linear } \\
62\end{array}$ & $\begin{array}{l}\text { linear } \\
62\end{array}$ & $\begin{array}{l}\text { linear } \\
76\end{array}$ & $\begin{array}{l}\text { linear } \\
46\end{array}$ & $\begin{array}{l}\text { linear } \\
58\end{array}$ & $\begin{array}{c}\text { linear } \\
58\end{array}$ & $\begin{array}{l}\text { linear } \\
72\end{array}$ & $\begin{array}{l}\text { linear } \\
46\end{array}$ \\
\hline R-squared & 0.6650 & 0.5670 & 0.6919 & 0.5906 & 0.6990 & 0.5762 & 0.7091 & 0.5963 \\
\hline
\end{tabular}

Regressions are weighted by the number of employees in 2010 and include controls for log average firm size and export intensity unless stated otherwise. Standard errors are robust and clustered by collective agreement and signature date. *, **, *** refer to statistical significance levels of $10 \%, 5 \%$ and $1 \%$ respectively. "Controls": affiliation status only; "bandwidth”: October 2010-August 2011; "Falsification”: placebo reform date (mid-May 2011) using agreements in post-reform period only (March 2011 - August 2011). 


\section{The role of representativeness and retroactivity}

We now consider the role of representativeness and retro-activity for the impact of extensions on the employment performance of non-affiliated and affiliated firms.

The degree of representativeness of employer associations is measured by the share of the workforce in affiliated firms in the total employment of the relevant sector. This definition is consistent with the representativeness criteria that were introduced as part of the 2012 labor market reform.

The results indicate that degree of representativeness does not appear to matter significantly for the impact of extensions for either affiliated or non-affiliated firms (Table 5a). In fact, almost all coefficients of the interactions between extension and representativeness are insignificant. Moreover, in additional robustness checks (available upon request), we find similar results when considering dummy variables defined at different representativeness thresholds ( $30 \%$ and $50 \%$, for instance).

This may be surprising given the systematic differences in the impact of extensions between affiliated and non-affiliated firms. The absence of an apparent role for representativeness here may be due to a number of factors. A technical explanation could be that it is not the variation in representativeness per se that matters but whether a majority of employees is represented or not. While we have looked at this as well, identification is not straightforward due to the very limited number of agreements with representativeness levels above 50\%. A substantive explanation could be that representativeness criteria based on a majority rule - as was introduced during the 2012 reform - are not sufficient for ensuring that the interests of nonaffiliated firms are fully taken into account. This may be either because a 50\% threshold is not high enough or because, in practice, bargaining is largely driven by market leaders in a sector with smaller affiliated firms in the same sector having little or no influence over the outcome of the negotiations. This suggests that representativeness criteria may need to be fine-tuned further or be complemented with a test of public interest as is the case in, for example, in the Netherlands.

All in all, the results do not allow drawing strong conclusions about the effectiveness of representativeness criteria in mitigating the adverse impact of extensions. However, even if 
representativeness criteria do not effectively ensure that the interests of non-affiliated firms are taken into account, representativeness criteria may still play a useful role in the longer-term by promoting the degree of organization among employers, particularly if implemented gradually over time. This may be valuable per se as it is may help to improve the quality of industrial relations as well as the degree of trust between social partners (see also Box 3.2 in IMF, 2016).

Table 5a. Results on the role of representativeness by affiliation status

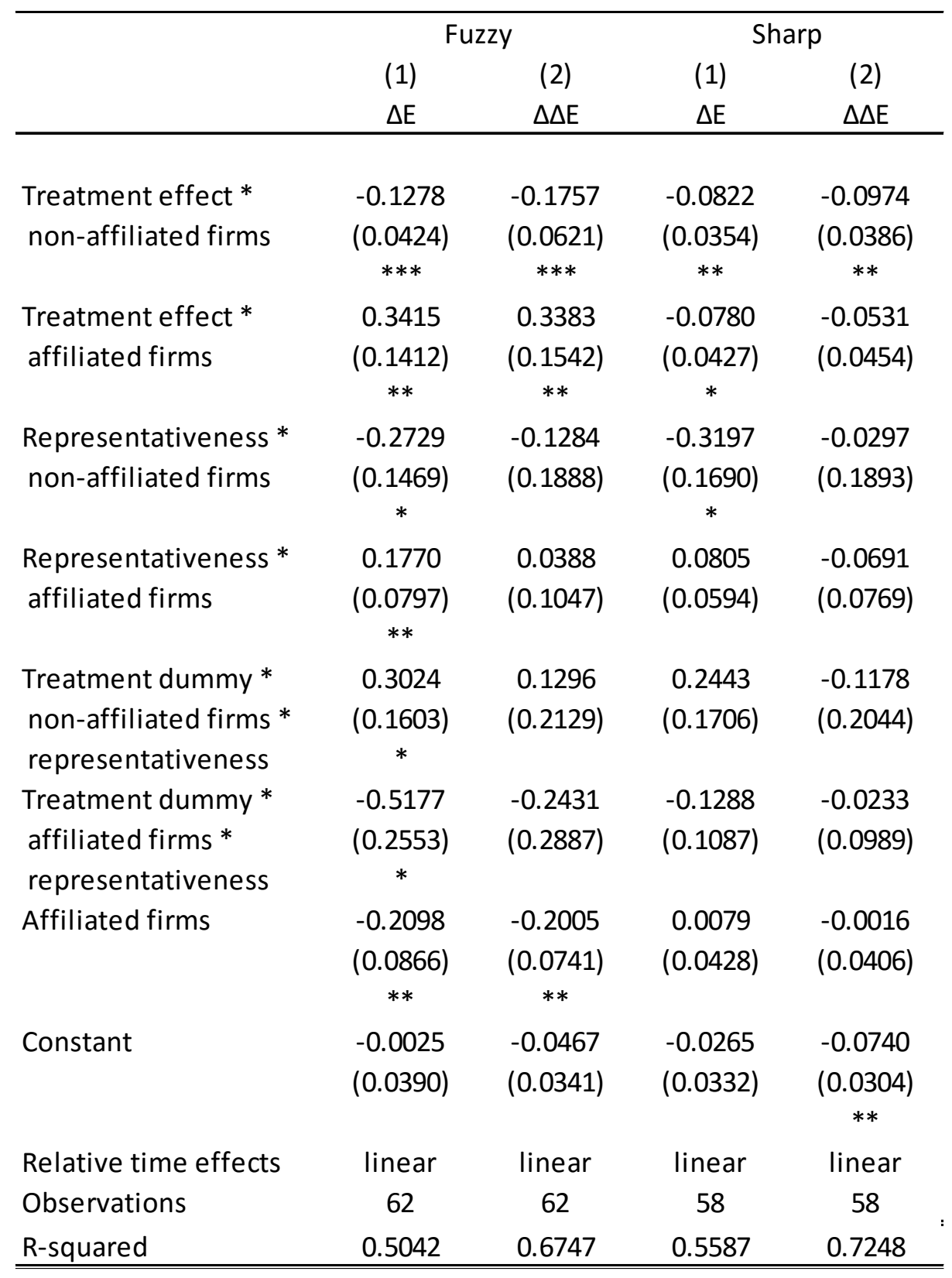

Regressions are weighted by the number of employees in 2010. Standard errors are robust and clustered by collective agreement and signature date. *,**, *** refer to statistical significance levels of $10 \%, 5 \%$ and $1 \%$ 
respectively. "Representativeness" is measured by the share of the workforce in affiliated firms in the total employment of the relevant sector.

Our next topic concerns the requirement for non-affiliated firms to retro-actively pay wage increases over the period from the entry-into-force date of collective agreements among affiliated firms to the publication date of the extension to non-affiliated firms. The rationale of applying retro-activity to extensions is to ensure that a level playing field between signatory and non-signatory firms is preserved, consistent with the spirit of sector-level bargaining and the logic behind extensions (Hijzen et al., 2016). However, their potential bite is considerable, particularly for liquidity-constrained firms: in fact, the typical time for processing an extension in Portugal in the period from late 2010 to early 2011 was about 180 days (about six months).

We find that retro-activity plays a potentially important role in explaining the adverse impact of extensions on employment among non-affiliated firms (Table 5b). The degree of retroactivity is measured by the number of days between the entry-into-force date of the collective agreement among affiliated firms and the publication date of the extension to non-affiliated firms. The negative average treatment effect reflects the impact of extensions on the change in employment growth for the typical administrative delay (180 days). The interaction of the treatment effect with the administrative delay gives the impact of a 1 day increase in the administrative delay on the change in the growth rate of employment following an extension. This is negative for non-affiliated firms, while it is insignificant or even positive for affiliated firms. The difference between affiliated and non-affiliated makes sense in principle since retroactivity should hit non-affiliated firms directly, while it may indirectly benefit affiliated firms by reducing competition from non-affiliated firms.

One can obtain an indication of the impact of extensions in the absence of retro-activity by considering their effect when there is no administrative delay in processing extensions, i.e. when the administrative delay is zero. This is done by re-estimating our model while defining the administrative delay in absolute value rather than as the difference from 180. Doing so implies that the treatment dummy now captures the impact of extensions in the absence of any administrative delay, rather than its impact for an average administrative delay shown in Table $5 \mathrm{~b}$ (results not reported). Under this specification, the overall impact of extensions on employment growth is reduced, and so is the extent to which the effects are concentrated among 
non-affiliated firms. In the case of the fuzzy RDD, the results indicate that retro-activity accounts for a substantial part of the adverse impact of extensions, with the negative effect on employment growth in non-affiliated firms falling by approximately 40\%, but their effects remain sizeable and concentrated among non-affiliated firms. By contrast, the results based on the sharp RDD suggest that extensions have no effect on employment growth in either nonaffiliated or affiliated firms in the absence of any administrative delay. All in all, the results suggest that retro-activity explains a significant part of the negative effect of extensions on employment growth among non-affiliated firms. ${ }^{16}$

At least in part, these results are likely to reflect the specific context during which the reform took place. Since collective agreements are public documents and there was little uncertainty as to whether or not a collective agreement would eventually be extended, retro-activity should not pose any problem as long as firms act rationally and there are no financial frictions. However, in a context where economic conditions were deteriorating rapidly and many firms were liquidity-constrained, the requirement to retro-actively pay wage increases seems to have slowed the growth rate of employment considerably. These findings are also consistent with the large job losses found in Martins (2014) in the four months after an extension is issued, mostly from reductions in hirings.

\footnotetext{
${ }^{16}$ These results should be interpreted with some caution since the discussion relies heavily on the assumed linear relationship between the length of the administrative delay and the impact of extensions and employment growth.
} 
Table 5b. Results on the role of retroactivity by affiliation status

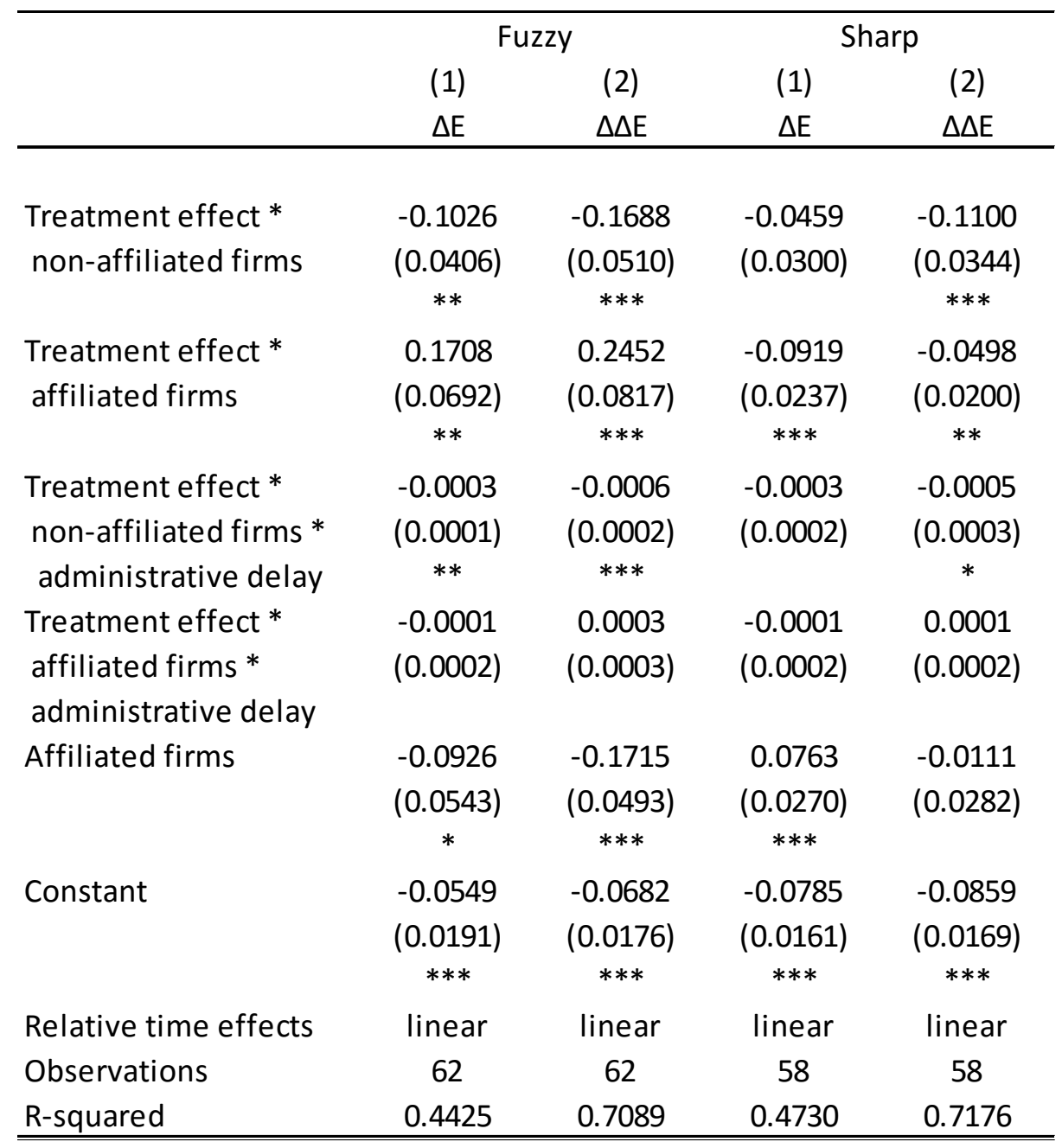

Regressions are weighted by the number of employees in 2010. Standard errors are robust and clustered by collective agreement. *, **, *** refer to statistical significance levels of $10 \%, 5 \%$ and $1 \%$ respectively. "Administrative delay" is defined in terms of the number of days since the entry-into-force date of the collective agreement among affiliated firms and the publication date of the extension to non-affiliated firms.

\section{RESULTS ON WAGE INEQUALITY}

Collective bargaining has been regarded as an important mechanism towards reducing wage inequality in a labor market (e.g. Blanchard et al, 2013). Moreover, this effect can be strengthened by extensions, as these can widen dramatically the coverage of binding minimum wages for different occupations and job levels in multiple industries in a given country. In this section, we examine empirically the effects of extensions on wages and wage inequality. 
In order to take account of the fact that wages are set separately for different job categories within agreements we focus on changes in residual wages and wage inequality within job categories, agreements, membership status and years. In an effort to control for the confounding role of composition effects when examining the impact of extensions on residual wages over time, we restrict the focus to workers who are employed in both 2010 and 2011. The analysis is conducted by examining the change between 2010 and 2011 in the $5^{\text {th }}, 10^{\text {th }}, 15^{\text {th }}$ and $20^{\text {th }}$ percentile of the residual wage distribution as well as the changes in each of these moments relative to the median. Apart from the change in the dependent variable, the econometric model is identical to that used for the analysis of employment growth in the previous section.

The results, presented in Table 6, show that extensions have a tendency to increase wages in the bottom of the distribution and reduce inequality. More specifically, extensions tend to increase wage growth by about 5 percentage points for workers in the fifth percentile of the residual wage distribution and tend to reduce the growth rate of the P50/P5 percentile ratio by a similar amount. Moreover, the effects of extensions on wages and inequality become smaller when moving up the residual wage distribution. Its effects on the wages of workers in the $20^{\text {th }}$ percentile of the residual wage distribution are insignificant in all specifications. ${ }^{17}$

All in all, these findings support a binding interpretation of the extension mechanism, which is in the background of the entire paper. They also suggest the existence of a trade-off between the adverse effects on employment documented in the previous section and the beneficial effects on the wages of low-wage workers and inequality documented here.

\footnotetext{
${ }^{17}$ We also find similar insignificant results for higher percentiles (available upon request).
} 
Table 6. Results on inequality

\begin{tabular}{|c|c|c|c|c|c|c|c|c|}
\hline \multicolumn{9}{|c|}{ Panel A. Fuzzy RDD } \\
\hline & $\begin{array}{c}(1) \\
\Delta \mathrm{p} 5\end{array}$ & $\begin{array}{c}(2) \\
\Delta(\mathrm{p} 50-\mathrm{p} 5)\end{array}$ & $\begin{array}{c}(3) \\
\Delta \mathrm{p} 10\end{array}$ & $\begin{array}{c}(4) \\
\Delta(\mathrm{p} 50-\mathrm{p} 10)\end{array}$ & $\begin{array}{c}(5) \\
\Delta \mathrm{p} 15\end{array}$ & $\begin{array}{c}(6) \\
\Delta(\mathrm{p} 50-\mathrm{p} 15)\end{array}$ & $\begin{array}{c}(7) \\
\Delta \mathrm{p} 20\end{array}$ & $\begin{array}{c}\text { (8) } \\
\Delta(\mathrm{p} 50-\mathrm{p} 20)\end{array}$ \\
\hline Treatment effect & $\begin{array}{c}0.0805 \\
(0.0373) \\
* *\end{array}$ & $\begin{array}{c}-0.0865 \\
(0.0481) \\
*\end{array}$ & $\begin{array}{c}0.0695 \\
(0.0400) \\
*\end{array}$ & $\begin{array}{l}-0.0755 \\
(0.0532)\end{array}$ & $\begin{array}{c}0.0710 \\
(0.0566)\end{array}$ & $\begin{array}{l}-0.0770 \\
(0.0721)\end{array}$ & $\begin{array}{c}0.0289 \\
(0.0285)\end{array}$ & $\begin{array}{l}-0.0349 \\
(0.0453)\end{array}$ \\
\hline Constant & $\begin{array}{l}-0.0286 \\
(0.0221)\end{array}$ & $\begin{array}{c}0.0501 \\
(0.0296)\end{array}$ & $\begin{array}{l}-0.0082 \\
(0.0205)\end{array}$ & $\begin{array}{c}0.0296 \\
(0.0297)\end{array}$ & $\begin{array}{l}-0.0248 \\
(0.0327)\end{array}$ & $\begin{array}{c}0.0463 \\
(0.0419)\end{array}$ & $\begin{array}{l}-0.0109 \\
(0.0165)\end{array}$ & $\begin{array}{c}0.0324 \\
(0.0259)\end{array}$ \\
\hline $\begin{array}{l}\text { Relative time effects } \\
\text { Observations } \\
\text { R-squared }\end{array}$ & $\begin{array}{c}\text { Linear } \\
62 \\
0.0875\end{array}$ & $\begin{array}{l}\text { Linear } \\
62 \\
0.1217\end{array}$ & $\begin{array}{l}\text { Linear } \\
\quad 62 \\
0.2290\end{array}$ & $\begin{array}{l}\text { Linear } \\
62 \\
0.2353\end{array}$ & $\begin{array}{l}\text { Linear } \\
62 \\
0.1727\end{array}$ & $\begin{array}{l}\text { Linear } \\
\quad 62 \\
0.1858\end{array}$ & $\begin{array}{l}\text { Linear } \\
62 \\
0.0644\end{array}$ & $\begin{array}{l}\text { Linear } \\
\quad 62 \\
0.1265\end{array}$ \\
\hline & $\begin{array}{c}(1) \\
\Delta \mathrm{p} 5 \\
\end{array}$ & $\begin{array}{c}(2) \\
\Delta(p 50-p 5) \\
\end{array}$ & $\begin{array}{c}\text { Panel } \\
(3) \\
\Delta \mathrm{p} 10 \\
\end{array}$ & $\begin{array}{c}\text { Sharp RDD } \\
(4) \\
\Delta(p 50-p 10) \\
\end{array}$ & $\begin{array}{c}5) \\
\Delta \mathrm{p} 15 \\
\end{array}$ & $\begin{array}{c}(6) \\
\Delta(p 50-p 15) \\
\end{array}$ & $\begin{array}{c}(7) \\
\Delta \mathrm{p} 20 \\
\end{array}$ & $\begin{array}{c}(8) \\
\Delta(p 50-p 20) \\
\end{array}$ \\
\hline Treatment effect & $\begin{array}{c}0.0493 \\
(0.0232) \\
* *\end{array}$ & $\begin{array}{l}-0.0476 \\
(0.0294)\end{array}$ & $\begin{array}{c}0.0494 \\
(0.0213) \\
* *\end{array}$ & $\begin{array}{l}-0.0477 \\
(0.0306)\end{array}$ & $\begin{array}{c}0.0519 \\
(0.0296) \\
*\end{array}$ & $\begin{array}{l}-0.0502 \\
(0.0392)\end{array}$ & $\begin{array}{c}0.0184 \\
(0.0147)\end{array}$ & $\begin{array}{l}-0.0166 \\
(0.0242)\end{array}$ \\
\hline Constant & $\begin{array}{l}-0.0310 \\
(0.0213)\end{array}$ & $\begin{array}{c}0.0522 \\
(0.0282) \\
*\end{array}$ & $\begin{array}{l}-0.0087 \\
(0.0185)\end{array}$ & $\begin{array}{c}0.0300 \\
(0.0275)\end{array}$ & $\begin{array}{l}-0.0266 \\
(0.0298)\end{array}$ & $\begin{array}{c}0.0478 \\
(0.0389)\end{array}$ & $\begin{array}{l}-0.0109 \\
(0.0155)\end{array}$ & $\begin{array}{c}0.0321 \\
(0.0247)\end{array}$ \\
\hline $\begin{array}{l}\text { Relative time effects } \\
\text { Observations }\end{array}$ & $\begin{array}{l}\text { Linear } \\
58\end{array}$ & $\begin{array}{l}\text { Linear } \\
58\end{array}$ & $\begin{array}{l}\text { Linear } \\
58\end{array}$ & $\begin{array}{l}\text { Linear } \\
58\end{array}$ & $\begin{array}{l}\text { Linear } \\
58\end{array}$ & $\begin{array}{l}\text { Linear } \\
58\end{array}$ & $\begin{array}{l}\text { Linear } \\
58\end{array}$ & $\begin{array}{l}\text { Linear } \\
58\end{array}$ \\
\hline R-squared & 0.1019 & 0.1442 & 0.2675 & 0.2510 & 0.2170 & 0.2120 & 0.0756 & 0.1275 \\
\hline
\end{tabular}

Results based on residuals from individual-level log base wage regression on job category dummies, collapsed by firm type (affiliated vs non-affiliated), collective agreement and year. $\Delta \mathrm{p} 5$ denotes the change in the $5^{\text {th }}$ percentile (of the cell's log base wage residual) between 2011 and 2010, $\Delta$ (p50-p5) denotes the difference between the median and the $5^{\text {th }}$ percentile in 2011, and similarly for the remaining dependent variables.

\section{CONCLUDING REMARKS}

In many countries, collective bargaining coverage is supported by administrative extensions that widen the reach of collective agreements beyond their signatory parties to all firms and workers in the same sector. Because of their potential role in reinforcing downward wage rigidity, extensions have become the focus of an increasingly intense policy debate in recent years. However, given the lack of hard evidence on the effects of extensions, the debate has largely tended to be based on subjective priors rather than factual arguments. By exploiting a natural experiment on collective bargaining in Portugal, this paper seeks to contribute to the ongoing discussions by providing new insights on the causal impact of extensions.

More specifically, this paper analyzed the causal impact of administrative extensions on employment growth using a natural experiment that resulted from the immediate suspension of 
extensions by the government that took office in Portugal in June 2011. Our analysis employs a regression discontinuity design that exploits the administrative delay in issuing extensions in combination with their suspension in June 2011 and novel matched employer-employeeagreement panel data. Importantly, this suspension resulted in a sharp and unanticipated decline in the probability that an extension was issued, several months prior to the change in government.

The results in the paper provide important insights for the debate on the role of extensions in countries undergoing adjustment periods, but also on collective bargaining more generally:

- $\quad$ First, our evidence indicates that extensions played an adverse role for employment growth during the period covered and, thereby, are likely to have amplified the unemployment response to the global financial crisis. However, we caution that the estimated adverse impact on employment growth may not necessarily generalize to periods with different economic conditions-that is, normal times, as opposed to the recession period covered here-or countries with different institutional settings (including with respect to retro-activity and representativeness).

- $\quad$ Second, the adverse effects of extensions on employment growth mainly concern firms that are not affiliated with an employer association, i.e. those that do not participate or are not represented in the bargaining of collective agreements. The concentration of adverse employment effects among non-affiliated firms suggests that extensions suit the interests of affiliated firms better than those of unaffiliated firms. This may imply that the lack of representativeness of employer associations is a potentially important factor behind the adverse effect of extensions.

- $\quad$ Third, however, the degree of representativeness of employer associations is not found to matter significantly for employment growth. This may reflect the low levels of, and limited variation in representativeness in our data, or that representativeness criteria (such as those implemented in Portugal in 2012) are not sufficient to ensure effectively that agreements are in the public interest. However, even if the introduction of the strict representativeness criteria in 2012 did not have a direct impact on employment growth, they are likely to have had a major impact on wage adjustment by greatly reducing the 
number of extensions issued, and therefore, indirectly, contributed positively to employment growth. Over the longer term, they also may help to promote employer organization, particularly when representativeness criteria are introduced gradually, and contribute to the quality of industrial relations as well as trust between social partners

- $\quad$ Fourth, the retro-activity with which extensions entered into force until the 2012 reform appears to be harmful for employment among non-affiliated firms. This has two important implications. It suggests that our results are to some extent specific to the weak economic conditions under which the "natural” experiment took place. If there were no uncertainty about the extension of agreements and firms were not liquidityconstrained, then retro-activity would not be expected to slow down employment growth. It also suggests that the 2012 reform may have helped to reduce the adverse effect of extensions by removing their retro-activity. Concerns that this undermines the spirit of sectoral bargaining and extensions can partly be addressed by shortening the administrative delay associated with issuing extensions.

- $\quad$ Fifth, there appears to be a trade-off between the adverse effects of extensions on employment growth and their beneficial effects on low wages and greater wage compression.

All in all, this paper considers many key features of sectoral bargaining, most of which for the very first time, using a novel type of matched data, and does so in a causal framework. Hopefully further research for other countries and time periods will assess to what extent our findings can be generalized more widely. 


\section{References}

Addison, J., P. Portugal \& H. Vilares, 2015, "Unions and Collective Bargaining in the Wake of the Great Recession”, IZA Discussion Paper No. 8943.

Blanchard, O., 2007, “Adjustment within the euro. The difficult case of Portugal”, Portuguese Economic Journal, 6(1), p. 1-21.

Blanchard, O., F. Jaumotte \& P. Loungani , 2014, "Labor market policies and IMF advice in advanced economies during the Great Recession," IZA Journal of Labor Policy, vol. 3(1), pp. 1-23.

Cardoso, Ana Rute \& Pedro Portugal, 2005, "Contractual Wages and the Wage Cushion under Different Bargaining Settings," Journal of Labor Economics, 23(4), 875-902, October.

Dustmann, Christian, Bernd Fitzenberger, Uta Schönberg, \& Alexandra Spitz-Oener, 2014, "From Sick Man of Europe to Economic Superstar: Germany's Resurgent Economy." Journal of Economic Perspectives, 28(1), 167-88.

De Ridder, M. and R. Euwals, 2016, "What are the wage effects of extending collective labour agreements? Evidence from the Netherlands”, CPB Background Document, April 2016.

Guimarães, P., F. Martins \& P. Portugal, 2015, “Upward nominal wage rigidity”, paper presented at DNB-IMF conference in Amsterdam, 29-30 October 2015.

Hahn, J., Todd, P., Van der Klaauw, W., 2001, “Identification and estimation of treatment effects with a regression-discontinuity design”, Econometrica, 69(1), pp. 201-209.

Hartog, J., E. Leuven and C. Teulings, 2002, "Wages and the bargaining regime in a corporatist setting: the Netherlands," European Journal of Political Economy, Vl. 18(2), pp. 317-331.

Haucap, Justus \& Pauly, Uwe \& Wey, Christian, 2001, "Collective wage setting when wages are generally binding An antitrust perspective," International Review of Law and Economics, 21(3), pp. 287-307, September.

Hijzen, A., P. Martins and J. Parlevliet, 2016, “A comparison of collective bargaining in Portugal and the Netherlands”, mimeo.

IMF World Economic Outlook, Chapter 3, 2016, “Time for a supply boost? Macroeconomic Effects of Labor and Product Market Reforms in Advanced Economies”, April.

Lee, D. S. \& Card, D., 2008, "Regression discontinuity inference with specification error," Journal of Econometrics, Vol. 142(2), pp. 655-674.

Lee, D.S. and Lemieux, T., 2010, “Regression Discontinuity Design in Economics”, Journal of Economic Literature, 48(2), pp. 281-355, June. 
Magruder, Jeremy R., 2012, "High Unemployment Yet Few Small Firms: The Role of Centralized Bargaining in South Africa," American Economic Journal: Applied Economics, 4(3), pp. 138-66, July.

Martins, P. S., 2009a, "Dismissals for Cause: The Difference That Just Eight Paragraphs Can Make," Journal of Labor Economics, 27(2), pp, 257-279.

Martins, P. S., 2009b, "Rent sharing before and after the wage bill," Applied Economics, 41(17), 2133-2151.

Martins, P. S., 2014, “30,000 Minimum Wages: The Economic Effects of Collective Bargaining Extensions”, IZA Discussion paper No. 8540, October 2014.

Martins, P. S., Solon. G. and Thomas, J. T., 2012, "Measuring What Employers Do about Entry Wages over the Business Cycle: A New Approach," American Economic Journal: Macroeconomics, 4(4), pp 36-55.

Moll, P.,1996, “Compulsory Centralization of Collective Bargaining in South Africa”, American Economic Review, 86(2), pp. 326-329.

Murtin, F., A. de Serres, and A. Hijzen. "Unemployment and the coverage extension of collective wage agreements.” European Economic Review 71:C., 2014, pp. 52-66. 


\section{Annex}

\section{Annex Table A1. Collective agreements and extensions}

\begin{tabular}{|c|c|c|}
\hline Agreement sector & Date agreement & Date extension \\
\hline Car sale & $08-10-2010$ & $10-01-2011$ \\
\hline Viana do Castelo retail & 08-10-2010 & 29-12-2010 \\
\hline Clinical analysis labs & 08-11-2010 & 28-02-2011 \\
\hline Wine trade sector & 22-11-2010 & 28-02-2011 \\
\hline Football clubs (players) & $15-12-2010$ & 22-03-2011 \\
\hline Cork industry, North, Office workers & 29-12-2010 & 26-04-2011 \\
\hline Wine industry, cellars & 10-01-2011 & 26-04-2011 \\
\hline Textile industry & 24-01-2011 & \\
\hline Hotels and restaurants, Centre and South & 24-01-2011 & 23-05-2011 \\
\hline Aveiro retail & 22-02-2011 & 23-05-2011 \\
\hline Electric and eletronic products & 22-02-2011 & 23-05-2011 \\
\hline Ropes industry & 28-02-2011 & \\
\hline Chemical and pharmaceutical retail & 28-02-2011 & 30-05-2011 \\
\hline Wood & 09-03-2011 & \\
\hline Pharmaceutical products retail & 29-03-2011 & \\
\hline Merchandising firms & 29-03-2011 & \\
\hline Viseu retail & 08-04-2011 & \\
\hline Wheat & 08-04-2011 & \\
\hline Coffee & 08-04-2011 & \\
\hline Driving schools & 08-04-2011 & \\
\hline Fish preserve industry & 26-04-2011 & \\
\hline Bread manufacturing, Lisbon & 26-04-2011 & \\
\hline Guarda, retail & 29-04-2011 & \\
\hline Poultry, slaughter & 09-05-2011 & \\
\hline Farming & 09-05-2011 & \\
\hline Meat, retail, South & $16-05-2011$ & \\
\hline Retail storehouses & 23-05-2011 & \\
\hline Bread manufacturing & 23-05-2011 & \\
\hline Fishing & $30-05-2011$ & \\
\hline Non-alcoholic beverages & 30-05-2011 & \\
\hline Cement & 08-06-2011 & \\
\hline Shoe manufacturing & $15-07-2011$ & \\
\hline Farming, Abrantes & $15-07-2011$ & \\
\hline Farming, Beja & 22-07-2011 & \\
\hline Construction sector & 08-08-2011 & \\
\hline Private schools & $16-08-2011$ & \\
\hline Clothing & $16-08-2011$ & \\
\hline Textile industry & $16-08-2011$ & \\
\hline
\end{tabular}

